\title{
Urease and Nitrification Inhibitors-As Mitigation Tools for Greenhouse Gas Emissions in Sustainable Dairy Systems: A Review
}

\author{
Maria P. Byrne ${ }^{1,2}{ }^{,}$John T. Tobin ${ }^{1}$, Patrick J. Forrestal ${ }^{3}$, Martin Danaher ${ }^{4}$, \\ Chikere G. Nkwonta ${ }^{4}{ }^{-}$, Karl Richards ${ }^{3}$, Enda Cummins ${ }^{2}$, Sean A. Hogan ${ }^{1}$ \\ and Tom F. O'Callaghan $1,5, *$ (D) \\ 1 Food Chemistry and Technology Department, Teagasc Food Research Centre, Moorepark, Fermoy, Co. Cork, \\ P61 C996 Cork, Ireland; maria-pilar.byrne@ucdconnect.ie (M.P.B.); john.tobin@teagasc.ie (J.T.T.); \\ sean.a.hogan@teagasc.ie (S.A.H.) \\ 2 School of Biosystems and Food Engineering, Agriculture and Food Science, University College Dublin, \\ Belfield, 4 Dublin, Ireland; enda.cummins@ucd.ie \\ 3 Teagasc, Johnstown Castle, Y35 Y521 Co. Wexford, Ireland; patrick.forrestal@teagasc.ie (P.J.F.); \\ karl.richards@teagasc.ie (K.R.) \\ 4 Food Safety Department, Ashtown Food Research Centre, Teagasc, Ashtown, 15 Dublin, Ireland; \\ martin.danaher@teagasc.ie (M.D.); chikere.nkwonta@teagasc.ie (C.G.N.) \\ 5 School of Food and Nutritional Sciences, University College Cork, Gaol Walk, T12 YN60 Cork, Ireland \\ * Correspondence: tom_ocallaghan@ucc.ie
}

Received: 9 June 2020; Accepted: 21 July 2020; Published: 27 July 2020

\begin{abstract}
Currently, nitrogen fertilizers are utilized to meet $48 \%$ of the total global food demand. The demand for nitrogen fertilizers is expected to grow as global populations continue to rise. The use of nitrogen fertilizers is associated with many negative environmental impacts and is a key source of greenhouse and harmful gas emissions. In recent years, urease and nitrification inhibitors have emerged as mitigation tools that are presently utilized in agriculture to prevent nitrogen losses and reduce greenhouse and harmful gas emissions that are associated with the use of nitrogen-based fertilizers. Both classes of inhibitor work by different mechanisms and have different physiochemical properties. Consequently, each class must be evaluated on its own merits. Although there are many benefits associated with the use of these inhibitors, little is known about their potential to enter the food chain, an event that may pose challenges to food safety. This phenomenon was highlighted when the nitrification inhibitor dicyandiamide was found as a residual contaminant in milk products in 2013. This comprehensive review aims to discuss the uses of inhibitor technologies in agriculture and their possible impacts on dairy product safety and quality, highlighting areas of concern with regards to the introduction of these inhibitor technologies into the dairy supply chain. Furthermore, this review discusses the benefits and challenges of inhibitor usage with a focus on EU regulations, as well as associated health concerns, chemical behavior, and analytical detection methods for these compounds within milk and environmental matrices.
\end{abstract}

Keywords: urease inhibitors; nitrification inhibitors; greenhouse gas emissions; dairy sustainability; residual food contaminants; nitrous oxide; ammonia gas

\section{Introduction}

Climate change is one of the greatest challenges facing the modern world with global populations expected to rise to 9 billion by the year 2050, creating further pressure to secure food supplies [1]. Climate change is known to cause many negative environmental effects and is accelerated by, and directly 
linked to, anthropogenic greenhouse gas (GHG) emissions, including carbon dioxide $\left(\mathrm{CO}_{2}\right)$, methane $\left(\mathrm{CH}_{4}\right)$, nitrous oxide $\left(\mathrm{N}_{2} \mathrm{O}\right)$, and harmful gas emissions that can negatively impact air and water quality including ammonia $\left(\mathrm{NH}_{3}\right)$ gas. To ensure maximum sustainable agricultural productivity while mitigating emissions, agriculture must increase carbon-sequestration, reduce GHG emissions, and lessen our dependence on fossil fuels [2]. The Intergovernmental Panel on Climate Change (IPCC) estimates that anthropogenic nitrogen $(\mathrm{N})$ inputs cause $60 \%$ of $\mathrm{N}_{2} \mathrm{O}$ emissions, through the use of fertilizers derived from animal waste.

There is a particular interest in lowering GHG and harmful gas emissions from dairy production, a sector that needs emission mitigation options but also one that is sensitive to the fate of farm inputs. European Union (EU) targets require a 20\% reduction in GHG emissions by 2020 and subsequent reductions of $40 \%$ by 2030 compared to 1990 emission levels [3,4]. The agricultural sector accounted for approximately 10\% of total GHG emissions in 2015 in the EU. Average European agricultural GHG emissions have declined by $20 \%$ from 1990 levels to 2015 . This reduction was achieved primarily by a $17 \%$ reduction in $\mathrm{N}_{2} \mathrm{O}$ emissions from agricultural soils, through the use of fewer $\mathrm{N}$ fertilizers and a $22 \%$ decrease in $\mathrm{CH}_{4}$ emissions achieved by reducing livestock numbers [5]. In 2016, the EU's National Emissions Ceilings Directive (2016/2284) on the reduction of national emissions of certain atmospheric pollutants was introduced and cited five primary air pollutants including NOx, non-methane volatile organic compounds (NMVOCs), sulfur dioxide $\left(\mathrm{SO}_{2}\right), \mathrm{NH}_{3}$, and carbon monoxide (CO). The use of $\mathrm{N}$-based fertilizers is known to produce GHGs including $\mathrm{CO}_{2}$ and $\mathrm{N}_{2} \mathrm{O} . \mathrm{N}_{2} \mathrm{O}$ is known to be particularly damaging to the environment and contributes to the depletion of the ozone layer. Over 170 countries have made various commitments to the Kyoto and Paris agreements as part of the effort to reduce the effects of global warming by lowering GHG and harmful gas emissions [6].

In 2019, the EU produced 151 billion liters of milk. This was followed by the US, India, Russia, China, Brazil, New Zealand, and Australia, who produced 96, 88, 30, 30, 24, 21, and 8.7 billion liters of milk, respectively. In order to meet EU and global commitments, the Dairy industry worldwide must embrace new technologies and strategies that reduce GHGs and harmful gas emissions. As the dairy industry continues to expand, it is evident that the use of inhibitor technologies will be necessary to ensure industry targets can continue to grow while continuing to address sustainability challenges. Inhibitor technologies have been shown to significantly reduce GHG and harmful gas emissions from $\mathrm{N}$ fertilizers and slurry $[7,8]$ and these technologies have been identified as promising mitigation options for agriculture [3]. Urease inhibitors work by blocking the active site of urease, slowing down urea hydrolysis, and limiting the amount of $\mathrm{N}$ lost to the atmosphere as $\mathrm{NH}_{3}$. Nitrification inhibitors generally work to inhibit soil enzymes, which are responsible for nitrification and denitrification and, ultimately, limit $\mathrm{N}$ losses by reducing $\mathrm{N}_{2} \mathrm{O}$ emissions and nitrate $\left(\mathrm{NO}_{3}{ }^{-}\right)$losses via leaching from soil. It is feasible that the mandatory use of such inhibitors will be passed into legislation in the near future to reduce EU emissions. For example, Germany has already implemented legislation that requires all urea fertilizers to incorporate urease inhibitors or be deeply integrated into the soil on application [9].

Although there are many benefits associated with the use of urease and nitrification inhibitors. In the year 2013, food safety concerns were raised around the use of the nitrification inhibitor Dicyandiamide (DCD), which appeared as a residual contaminant in dairy products [10]. This finding highlights the fact that although these inhibitor technologies may offer useful mitigation options for agriculture, more research is needed to thoroughly risk assess their potential to enter the food chain through grazing cattle. While both urease and nitrification inhibitors have the potential to effectively reduce $\mathrm{N}$ losses, it is important to note that although they are often grouped together as "inhibitors", they are chemically different, and have different modes of action [9]. Many inhibitor products have already been approved and are currently on the market. For some, extensive toxicology and environmental fate studies have been completed. However, further research would be beneficial to ensure that these mitigation tools do not pose any food safety-related issues in future. Such research would include the development of advanced detection methods for these compounds in food matrices, and determine the best practice for use of these products, which could in turn drive the identification 
and establishment of environmental and food safety maximum residual levels (MRL). These measures would contribute to sustainable growth of the dairy sector while maintaining high-quality milk products.

\section{Nitrogen-Based Gas Emissions and Their Formation}

Intensive agriculture is heavily reliant on $\mathrm{N}$ fertilizers in order to meet the demands of a global population, which continues to grow exponentially. Currently, over $70 \%$ of $\mathrm{N}$ utilized by plants comes from inorganic fertilizer sources [11], which contributes to both GHGs and $\mathrm{NH}_{3}$ emissions. One potent GHG associated with land application of $\mathrm{N}$-based fertilizers is $\mathrm{N}_{2} \mathrm{O} . \mathrm{N}_{2} \mathrm{O}$ has a 100-year atmospheric half-life ( $\mathrm{t} 1 / 2$ the time needed for half of the starting material to decay) and according to the 5th IPCC Assessment report, the global warming potential of $\mathrm{N}_{2} \mathrm{O}$ is $265-298$ times more than $\mathrm{CO}_{2}$ [12]. It is also known to deplete ozone [13]. Ammonium nitrate (AN)-based fertilizers, in particular, are associated with $\mathrm{N}_{2} \mathrm{O}$ emissions from temperate grassland soils [14], and the $\mathrm{NO}_{3}{ }^{-}$component of $\mathrm{AN}$ fertilizers is prone to leaching, which leads to eutrophication and impacts negatively on aquatic environments [15].

The main factors affecting $\mathrm{N}$ losses in the form of $\mathrm{N}_{2} \mathrm{O}$ emissions due to microbial activity include soil structure i.e., water content and drainage, soil temperature and $\mathrm{pH}, \mathrm{N}$ content, decomposable organic material [16,17], soil redox potential [18], and availability of carbon [19]. N losses can also occur due to $\mathrm{NH}_{3}$ volatilization, which is estimated to result in average global $\mathrm{N}$ losses ranging from $16-40 \%$ [9]. Agricultural $\mathrm{N}$ losses are estimated to account for over $90 \%$ of $\mathrm{NH}_{3}$ emissions in Europe [20] virtually all Irish $\mathrm{NH}_{3}$ emissions are attributed to agricultural practices [21]. Factors that influence $\mathrm{NH}_{3}$ losses include soil moisture, soil temperature and $\mathrm{pH}$, wind velocity, soil organic $\mathrm{C}$, and $\mathrm{N}$ fertilizer type [22]. The type of $\mathrm{N}$ fertilizer utilized is an important determining factor in $\mathrm{N}$ loss pathways as it can affect the ratio of soil $\mathrm{NO}_{3}{ }^{-}$to ammonium $\left(\mathrm{NH}_{4}{ }^{+}\right)$concentrations [23]. $\mathrm{N}$ fertilizer application rate and time of application can also affect the amount of $\mathrm{N}_{2} \mathrm{O}$ produced [15].

Denitrification represents a significant pathway for $\mathrm{N}_{2} \mathrm{O}$ emissions and is the main pathway of $\mathrm{N}_{2} \mathrm{O}$ emissions from Irish soils. Denitrification occurs under anaerobic conditions and is carried out by heterotrophic bacteria that utilize carbon (C) as an energy source and thereby reduce $\mathrm{NO}_{3}{ }^{-}$to nitrogen gas $\left(\mathrm{N}_{2}\right)$. During denitrification, $\mathrm{NO}_{3}{ }^{-}$acts as an electron acceptor and is reduced to nitrite $\left(\mathrm{NO}_{2}{ }^{-}\right)$ followed by nitric oxide (NO) [24]. Nitric oxide is toxic to bacterial cells and is quickly transformed into $\mathrm{N}_{2} \mathrm{O}$, which is eventually converted back to atmospheric $\mathrm{N}_{2}$.

An additional pathway for agricultural $\mathrm{N}_{2} \mathrm{O}$ emissions is nitrification. During nitrification, $\mathrm{NH}_{4}{ }^{+}$ ions and $\mathrm{NH}_{3}$ are oxidized and converted to $\mathrm{NO}_{2}{ }^{-}$and $\mathrm{NO}_{3}{ }^{-}$by nitrifying bacteria. When $\mathrm{NH}_{4}{ }^{+}$ oxidizes $\mathrm{NO}_{2}{ }^{-}, \mathrm{N}_{2} \mathrm{O}$ is produced as an intermediate product and is lost to the atmosphere [24]. Other potential negative impacts of excess $\mathrm{N}$ include aquatic acidification, loss of biodiversity, and negative human health impacts such as methemoglobinemia in children (blue baby syndrome) following consumption of water with $\mathrm{NO}_{3}{ }^{-}$concentrations exceeding $10 \mathrm{mg} \mathrm{L}^{-1}$ [25].

Urea $\left(\mathrm{NH}_{2} \mathrm{CONH}_{2}\right)$ is a reactive organic source of nitrogen widely produced industrially as a fertilizer. Urea is a cheaper source of $\mathrm{N}$ than $\mathrm{AN}$ or ammonium sulfate (AS) [26] and is the most widely utilized fertilizer globally. Emissions of $\mathrm{N}_{2} \mathrm{O}$ from urea tend to be much lower than AN fertilizer emissions, as the primary source of $\mathrm{N}$ provided by urea must undergo two conversions before it can be affected by nitrification or denitrification to produce $\mathrm{N}_{2} \mathrm{O}$. In contrast, $\mathrm{AN}$ provides $\mathrm{NO}_{3}{ }^{-}$and $\mathrm{NH}_{4}{ }^{+}$ directly to the soil leaving it vulnerable to nitrification and denitrification processes, which, under suitable conditions, leads to rapid loss of $\mathrm{N}$ as $\mathrm{N}_{2} \mathrm{O}$. However, $\mathrm{N}$ losses from urea occur due to $\mathrm{NH}_{3}$ volatilization, which happens when urea is applied to the soil surface and is subsequently hydrolyzed by urease, the ubiquitous soil enzyme, produced by soil bacteria. When urea is hydrolyzed, it forms an unstable intermediate, carbamate, which is quickly transformed into $\mathrm{NH}_{3}$. Volatilization of $\mathrm{NH}_{3}$ (Figure 1) can impact air quality, which can negatively affect human health, cause environmental pollution, and economic losses to farmers [27]. 


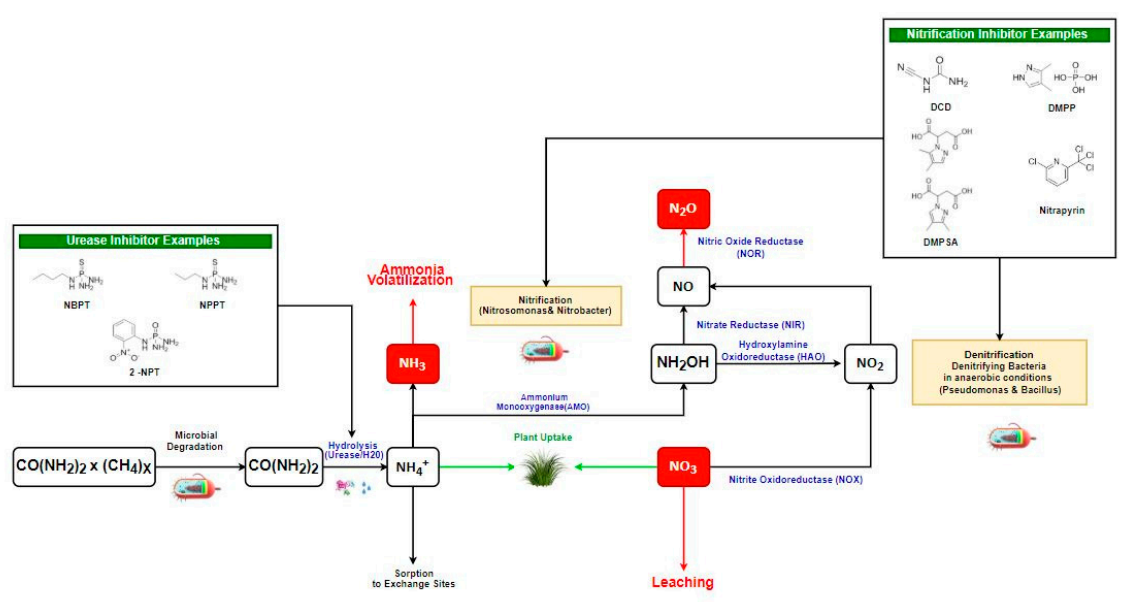

Figure 1. Primary pathways for Nitrogen loss.

In recent years, mitigation technologies including urease inhibitors and nitrification inhibitors have been explored to reduce emissions and $\mathrm{N}$ losses from agricultural fertilizer usage. Urease inhibitors work by blocking the active site of urease, slowing down urea hydrolysis, and limiting the amount of $\mathrm{N}$ lost to the atmosphere as $\mathrm{NH}_{3}$. Nitrification inhibitors generally work to inhibit soil enzymes such as $\mathrm{N}$ reductase, which are responsible for nitrification and ultimately, limit $\mathrm{N}$ losses by reducing $\mathrm{N}_{2} \mathrm{O}$ emissions, and $\mathrm{NO}_{3}{ }^{-}$losses via leaching from soil. Both urease and nitrification inhibitors can effectively reduce N loss and reduce GHG emissions. However, it is important to note that although they are often grouped together as "inhibitors", they are chemically different and have different modes of action [9]. Many inhibitor products have already been approved and are currently on the market. For some, extensive toxicological and environmental fate studies have been completed. However, further research would be beneficial to ensure that these mitigation tools do not pose any food safety-related issues in future. Such research would include the development of advanced detection methods for these compounds in food matrices, best practices for the use of these products, and the identification and establishment of environmental and food safety MRL. These measures would contribute to sustainable growth of the dairy sector while maintaining high-quality milk products.

\section{Urease and Nitrification Inhibitor EU Regulation}

The regulation of fertilizer content and the use of urease and nitrification inhibitors in Europe fall under Regulation (EC) No 2003/2003, which aims to ensure that all fertilizers used in the EU adhere to the same efficacy and safety regulations. This is done by safeguarding technical requirements, which are implemented consistently through all member states. Annex I, of the regulation, further categorizes fertilizers and their additives based on their product function (i.e., inorganic, synthetic, and organic fertilizers, inhibitors, soil improvers, liming agents, etc.) The fertilizer can then be classified as a European Community (EC) product, which stipulates that it is safe for use and possesses the required nutrient content. After EC designation, the fertilizer may be distributed and utilized in EU member states [28]. Regulation (EC) No 2003/2003 states that nitrification and urease inhibitors may be added to nitrogenous EC fertilizer types such as AN and urea fertilizers. The regulation states the minimum and maximum inhibitor augmentation as a percentage mass of the total $\mathrm{N}$ content (Table 1). Furthermore, it states that if the fertilizer is augmented with an inhibitor, it must be clearly labelled "with nitrification inhibitor" or "with urease inhibitor". The seller must also inform the user of the correct rates and timing of application [28]. Various amendments have been made to Regulation (EC) No 2003/2003 in subsequent years including (EU) No 1257/2014 and (EU) 2019/1102. Another EU regulation that ensures the proper registration, evaluation, authorization, and restriction of chemicals (REACH) came into effect in 2007, in order to protect human health and the environment. This regulation also focuses on facilitating the free movement of chemicals in the EU, advancing innovation in the EU chemical industry, and reducing animal testing through its "read-across approach" for chemicals that possess similar physiochemical and/or structural properties and 
that are likely to have similar toxicological effects. REACH registered chemicals undergo risk assessments for potential hazards. Strict hazard management plans are also in place to ensure REACH compliance. Urease and nitrification inhibitors are also registered under REACH legislation.

Various nitrification and urease inhibitors of commercial interest have REACH status including $\mathrm{N}$-(n-butyl) thiophosphoric triamide (NBPT), N-propyl- thiosphosphoric- triamide (NPPT), $\mathrm{N}$-(2-nitrophenyl) phosphoric triamide (2-NPT), dicyandiamide (DCD), 3,4-dimethyl-1H-pyrazole phosphate (DMPP), 4,5-dimethylpyrazole-1-yl-succinic acid (DMPSA) and Nitrapyrin. Minimum and maximum allowances (inhibitor augmentation (\%) by mass of the total $\mathrm{N}$ present in the fertilizer) as $\mathrm{AN}$ and urea have also been established for NBPT, NPPT, 2-NPT, DCD, DMPP, and DMPSA and are set out in the regulations. Currently, there are no MRLs in place for these inhibitors but it is possible that regulations regarding MRLs will be proposed in the future. The European Food Safety Agency (EFSA) has, however, introduced a tolerable daily intake (TDI) of $1 \mathrm{mg} / \mathrm{kg}$ bodyweight for DCD [29]. The implementation of future MRLs could aid in safeguarding the chemical safety of urease and nitrification inhibitors and therefore prevent any future food safety concerns while upholding the quality of dairy products.

Table 1. Inhibitor augmentation and corresponding EU regulations.

\begin{tabular}{|c|c|c|c|c|c|c|c|}
\hline \multicolumn{8}{|c|}{ Inhibitor Augmentation Based on \% $(w / w)$ by Mass of the total $\mathrm{N}$ Present as AN and Urea } \\
\hline Compound Name & $\begin{array}{l}\text { Inhibitor } \\
\text { Class }\end{array}$ & $\begin{array}{l}\operatorname{Min} \% \\
(w / w)\end{array}$ & $\begin{array}{l}\operatorname{Max} \% \\
(w / w)\end{array}$ & EC No ${ }^{1}$ & RR Status ${ }^{2}$ & TTB $^{3}$ & References \\
\hline NBPT & \multirow{3}{*}{$\begin{array}{l}\text { Urease } \\
\text { Inhibitor }\end{array}$} & 0.09 & 0.2 & $435-740-7$ & \multirow{3}{*}{ Full } & $100-1000$ tpa & [30] \\
\hline $\begin{array}{l}\text { Mixture NBPT and NPPT } \\
\text { (ratio 3:1 (1)) }\end{array}$ & & 0.02 & 0.3 & $700-457-2$ & & 10-100 tpa & [31] \\
\hline 2-NPT & & 0.04 & 0.15 & 477-690-9 & & 10-100 tpa & [30] \\
\hline DCD & & 2.3 & 4.5 & $207-312-8$ & \multirow{4}{*}{ Full } & $10,000-100,000$ tpa & [30] \\
\hline Nitrapyrin & & $\mathrm{N} / \mathrm{A}$ & N/A & $217-682-2$ & & $100-1000$ tpa & [32] \\
\hline DMPP & Nitrification & 0.8 & 1.6 & $424-640-9$ & & $100-1000$ tpa & {$[31]$} \\
\hline $\begin{array}{c}\text { Isomeric mixture of } \\
\text { 2-(3,4-dimethylpyrazole- } \\
\text { 1-yl)-succinic acid and } \\
\text { DMPSA }\end{array}$ & Inhibitor & 0.8 & 1.6 & $940-877-5$ & & $100+$ tpa & [33] \\
\hline
\end{tabular}

${ }^{1}$ European Community number (EC No) unique seven-digit identifier that is assigned under substances under Reach regulation; ${ }^{2}$ REACH Registration (RR); ${ }^{3}$ Total Tonnage Band (TTB) the amount of substance that can be purchased without notification to the authorities (in tons per annum, tpa).

\section{Urease Inhibitors Types, Mode of Action, and Their Role in GHG Reduction}

Hydrolysis of urea is catalyzed by urease, which is produced by soil bacteria and results in the emission of $\mathrm{NH}_{3}$. The urea molecule fits inside the active site cavity of urease, as a monodentate ligand, which ultimately leads to hydrolysis of the urea molecule [34]. There are many types of urease enzyme and urease activity is common in prokaryotes and eukaryotes, including fungi and plants [35].

There are four different ways in which urease inhibitors can inhibit urease enzymes and delay urea hydrolysis. These include (a) reversible competitive, (b) reversible non-competitive, (c) irreversible binding to allosteric sites on the enzyme, and (d) irreversible suicide substrate (also known as mechanism-based inhibition), where the enzyme binds to a substrate analog and forms an irreversible complex via covalent bonding during the normal catalysis reaction (Table 2) [36]. Urease inhibitors generally work by inhibiting the active site of the enzyme to slow down the hydrolysis of urea. Reversible inhibition utilizes non-covalent interactions with urease enzymes in the form of hydrogen bonding and/or hydrophobic interactions. Reversible inhibition may either be competitive, where the inhibitor competes with urea for the urease active site, with the resulting inhibition being proportional to the concentration of urea present; or non-competitive where the inhibitor binds to allosteric sites on the urease enzyme, resulting in a change of shape and inactivation of the enzyme. This inhibition type is not proportional to the concentration of urea present. Irreversible urease inhibitors possessing functional groups that interact with amino acid groups at the active site of the urease enzyme are also available [37]. 
Urease inhibitors can come in liquid form or as a coating on fertilizer granules. The principal factor affecting the percentage $\mathrm{N}$ loss from the soil, due to $\mathrm{NH}_{3}$ volatilization, is the biodegradation rate of the inhibitor. Consequently, the rate of biodegradation and persistence of inhibitors in the soil will determine their performance in mitigation of $\mathrm{N}$ losses. In addition, the use of urease inhibitors is also beneficial in controlling soil $\mathrm{pH}$ and aids in the prevention of localized zones of high $\mathrm{pH}$, which occur around fertilizer granules of untreated urea. The rise in $\mathrm{pH}$ observed around untreated urea granules is due to the fact that $\mathrm{NH}_{3}$ volatilization is $\mathrm{pH}$ dependent. Urea hydrolysis requires $\mathrm{H}^{+}$ions, which are obtained from the soil in a ratio of $2: 1\left(\mathrm{H}^{+}\right.$:urea). The consumption of $\mathrm{H}^{+}$ions during this reaction results in increased soil $\mathrm{pH}$, which drives further $\mathrm{NH}_{3}$ volatilization [9].

Urease inhibitors are classified into two main categories i.e., metal complexes and organic compounds [38]. Insoluble sulfide-forming metals exhibit the most potent inhibition properties due to reactions with sulfhydryl groups of urease. $\mathrm{Ag}^{+1}$ and $\mathrm{Hg}^{2+}$ can completely inactivate urease activity in solutions containing concentrations of up to $10^{-6} \mathrm{M}$ urease. In general, metal ions follow the following order of efficacy in inhibiting urease activity.

$$
\mathrm{Ag}^{+} \sim \mathrm{Hg}^{2+}>\mathrm{Cu}^{2+}>\mathrm{Cd}^{2+}>\mathrm{NI}^{2+}>\mathrm{Co}^{2+}>\mathrm{Fe}^{2+}>\mathrm{Mn}^{2+}
$$

This order can, however, vary depending on the urease enzyme type. These inhibitors are considered to be non-competitive [38]. Other metal complexes reported to exhibit inhibitory properties include organotin (IV), vanadium (IV), bismuth (III), and thiocyanato-coordinated manganese (III) [37].

Organic type inhibitors can generally be divided into two classes of structural urea analogs such as hydroxamic acid and compounds that impact the urea hydrolysis reaction mechanism. The latter include organophosphorus compounds (amides and esters of phosphoric acid including phosphoramides), thiol compounds, quinones, boron compounds, and bismuth compounds [39]. Organophosphorus compounds are the most widely utilized urease inhibitors in agriculture and are defined as organic molecules containing a phosphate molecule. The presence of phosphate is useful as it is a well-known, weak urease inhibitor. Amides and esters of phosphoric acid are slow-binding actors that inhibit urease in a time-dependent manner and are known to be amongst the strongest urease inhibitors. Phosphoramides belong to this chemical class.

Phosphoramides act as strong inhibitors of urease due to their similarities in transition state and enzyme reactions as well as their ability to bind strongly to the active metallocentre site of urease [26]. Phosphoramides can include both simple and complex compounds from phosphoramidite and diamidophosphate to substituted phenyl phosphorodiamidates and $\mathrm{N}$-acyl phosphoric triamides. Phosphoramidite inhibits jack bean urease reversibly (rate constant $\mathrm{K}_{\mathrm{i}}=1.9 \mathrm{mM}$; dissociation rate $=8.4 \times 10^{-4} / \mathrm{s}$ ), with $\mathrm{N}$-acyl phosphoric triamides and phenyl phosphorodiamidates exhibiting comparable rate constants [38]. Phenyl phosphorodiamidates are more active as plant urease inhibitors than microbial urease inhibitors. Some phosphoramides inhibit urease via the formation of chelated complexes in the Nickel (Ni) metallocentre of the urease enzyme. Examples include phosphoric monoamide and phenyl phosphorodiamidates [38]. Kinetic studies have shown that inhibition of urease via phosphoramide-type compounds is achieved via the formation of hydrolysis by-products such as diamidophosphate (DAP). DAP has a tetrahedral structure that almost perfectly replaces all three water molecules present in the enzyme's active site [40,41].

One interesting group in this class are derivatives of thiophosphoric acid. These compounds must first be oxidized to Oxon analogs in order to function as urease inhibitors. NBPT is a good example of this as it is a precursor urease inhibitor and its Oxon analog (NBPTo) actively inhibits urease. NBPT is also the most commonly utilized agricultural urease inhibitor [40]. Recent studies have demonstrated that NBPT irreversibly binds to urease where it is hydrolyzed, resulting in the production of monoamidothiophosphoric acid (MATP), which then binds to the two Ni (II) ions in the urease active site [26,42]. Other examples of amides and esters of phosphoric acid that exhibit potent urease inhibition include phosphoric triamide (PTA), 
phenylphosphorodiamidate (PPD), 4-chlorophenylphosphorodiamidate, $\mathrm{N}$ (diaminophosphinyl) benzamide, $\mathrm{N}$-(diaminophoshinyl)-4-fluoro-benzamide, and phosphoric acid buffer $(\mathrm{pH}<7.5)$ [40].

Table 2. Inhibition classification and properties of urease and nitrification inhibitors of agricultural interest.

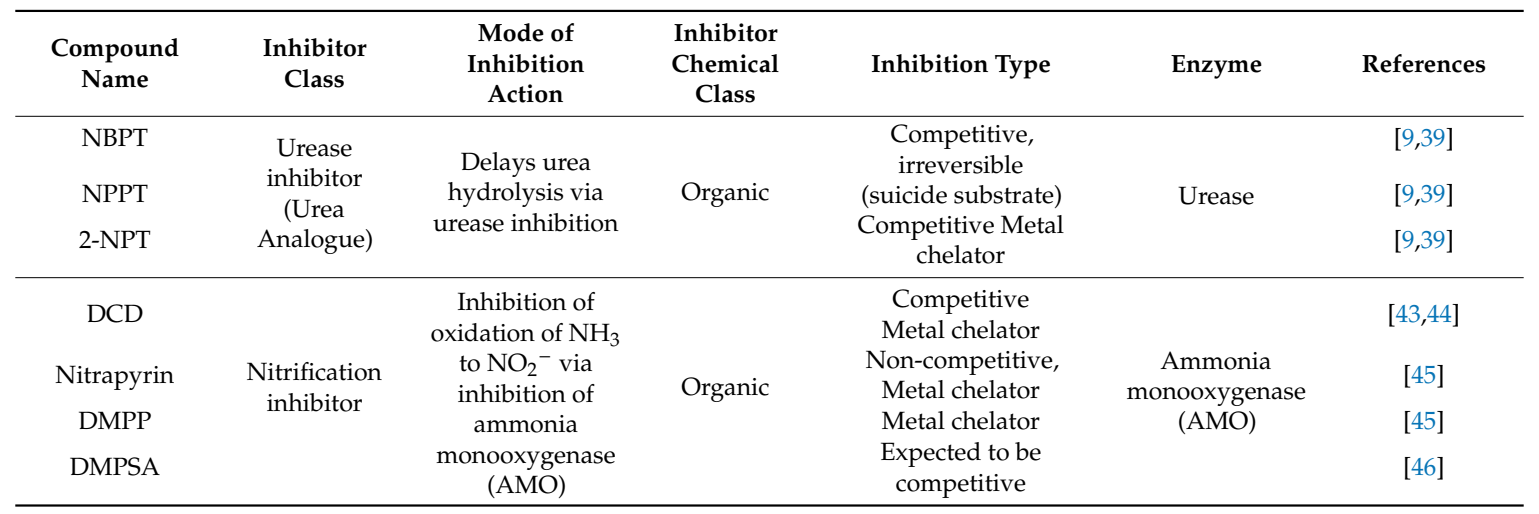

\subsection{N-(n-butyl) Thiophosphoric Triamide (NBPT)}

The most successful urease inhibitor currently on the market is the phosphoramide NBPT, which was first branded as Agrotain ${ }^{\circledR}$ in the mid-1990s [9]. NBPT has been shown to reduce emission of $\mathrm{NH}_{3}$ by up to $84 \%$, which is comparable to the $83 \%$ reduction in $\mathrm{NH}_{3}$ emissions observed when using Calcium Ammonium Nitrate (CAN). Switching from CAN to protected urea also aids in the indirect reduction of $\mathrm{N}_{2} \mathrm{O}$ emissions [47]. The yield gain via the use of NBPT with urea is cited to vary from 0.8 to $10.2 \%$ depending on the crop species [9]. The use of NBPT in conjunction with urea has been found to improve the dry matter yield of perennial ryegrass, by improving the performance of urea. Urea-amended with NBPT produced dry matter yields comparable to CAN fertilizers indicating that the former can aid in the reduction of both $\mathrm{N}_{2} \mathrm{O}$ and $\mathrm{NH}_{3}$ emissions [48,49].

NBPT inhibits urease by blocking three active sites in the urease enzyme thereby delaying urea hydrolysis and delaying $\mathrm{NH}_{3}$ volatilization. In doing this, NBPT acts as a competitive inhibitor and an irreversible suicide substrate. It is considered a urea analog possessing a structure similar to that of urea. The resulting inhibition is proportional to the concentration of urea present. When NBPT encounters urease, a trident bond is formed with two $\mathrm{Ni}$ centers and one $\mathrm{O}_{2}$. A carbamate bridge links the two metals, making it harder for urea to reach the active Ni center of the urease enzyme $[9,34,50]$. NBPT is an indirect urease inhibitor and is first converted to NBPTo, its Oxon analog, to facilitate urease inhibition, which occurs under aerobic conditions [9]. However, the direct application of NBPTo is not as efficient as NBPT application due to the instability of NBPTo.

Inhibition of urease by NBPT usually lasts three to seven days (d) as new urease enzyme production overwhelms the inhibitor. This is desirable as it allows more time for urea to be incorporated into the soil and reduces the chance of $\mathrm{NH}_{3}$ volatilization. For this reason, NBPT is often added into urea fertilizers. NBPT mitigates $\mathrm{NH}_{3}$ volatilization by controlling the rise in $\mathrm{pH}$ that occurs during urea hydrolysis, resulting in the production of two units of $\mathrm{NH}_{4}{ }^{+}$and $\mathrm{CO}_{2}$ and reduces the soil concentration of $\mathrm{NH}_{4}{ }^{+}$around the urea granule. These effects impact the equilibrium of $\mathrm{NH}_{4}{ }^{+}$(soil), $\mathrm{NH}_{3}$ (soil), and $\mathrm{NH}_{3}$ (gas) [51], which results in slower urea hydrolysis and ultimately allows more time for the fertilizer to be incorporated into the soil via rainfall or irrigation and consequently protects the applied $\mathrm{N}$ from volatilization [52].

The physicochemical properties of NBPT are shown in (Table 3). Structurally, NBPT is an amphiphilic molecule possessing both a polar phosphoramide region and a lipophilic butyl chain allowing it to interact with both polar and non-polar phases [53,54]. NBPT is considered a surface-active material (a surfactant) with a surface tension of $49.4 \mathrm{mN} / \mathrm{m}\left(1.05 \mathrm{~g} / \mathrm{L}\right.$ at ca. $\left.22^{\circ} \mathrm{C}\right)$. The degradation half-life $\left(\mathrm{DT}_{50}\right)$ value for NBPT is reported to be $58 \mathrm{~min}$ at $\mathrm{pH} 3.0,92 \mathrm{~d}$ at $\mathrm{pH} 7.0$ and $16 \mathrm{~d}$ at $\mathrm{pH} 11.0$ at $25^{\circ} \mathrm{C}$ [55]. Engel et al. [56] found that NBPT degraded in acidic to slightly alkaline soils (pH 5.1-7.6) mostly due to chemical hydrolysis. 
Table 3. Physiochemical properties of urease and nitrification inhibitors of agricultural interest.

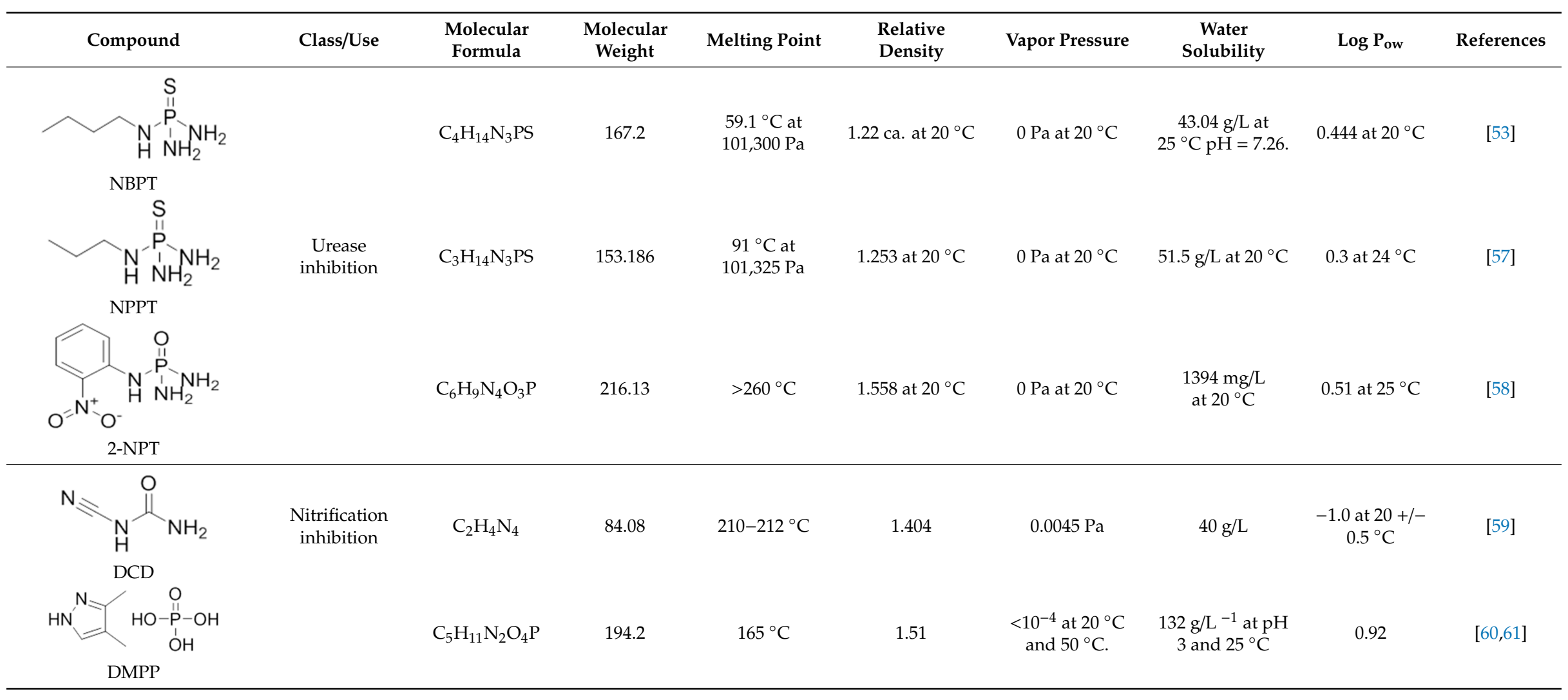


Table 3. Cont

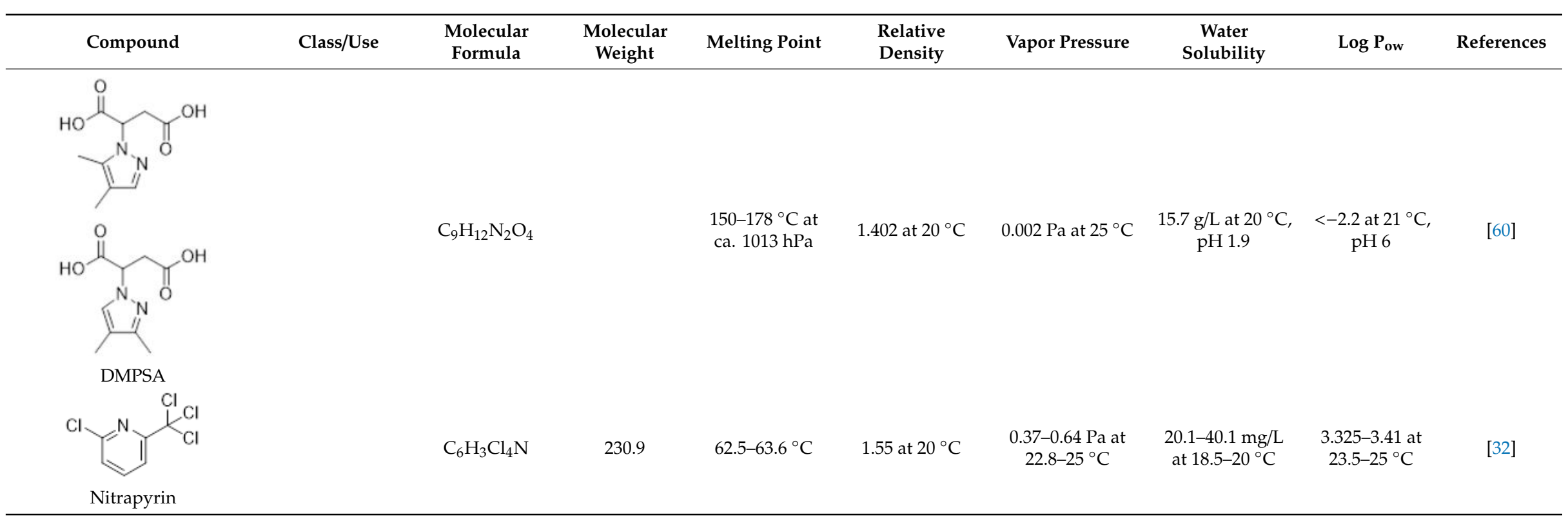


Major hydrolysis components of NBPT have been identified as N-(n-butyl) thiophosphoric diamide and n-Butylamine (NBA). NBPT is pH labile and chemical hydrolysis appears to be an essential function of its break-down in acidic conditions (Figure 2). Engel et al. [56] determined the half-life of NBPT at $\mathrm{pH}$ 4.0. 5.0, 6.0, and 7.2 to be $0.437,1.60,42.44$, and $487.1 \mathrm{~d}$, respectively, whereas that of NBPTo was $0.0430,0.203,6.25$, and $57.91 \mathrm{~d}$, respectively. Decay constants for NBPT and NBPTo followed pseudo-first-order kinetics during chemical hydrolysis and were directly related to hydrogen ion concentration. The half-Life of NBPT is 7-10 times greater that of NBPTo because the $\mathrm{P}=\mathrm{O}$ bond in NBPTo carries a larger positive charge, leaving it more prone to nucleophilic attack from water and susceptible to cleavage of $\mathrm{P}-\mathrm{N}$ bonds. The study concluded that under acidic conditions chemical hydrolysis is likely the dominant pathway for NBPT and NBPTo breakdown. Under alkaline conditions, biotic breakdown of these compounds via microorganisms becomes more significant [56]. Lower NBPT efficiency in acidic soils was also observed by Tao et al. who related this behavior to both soil $\mathrm{pH}$ and microbial activity [62]. This finding is further cited by Dominguez et al. [50].

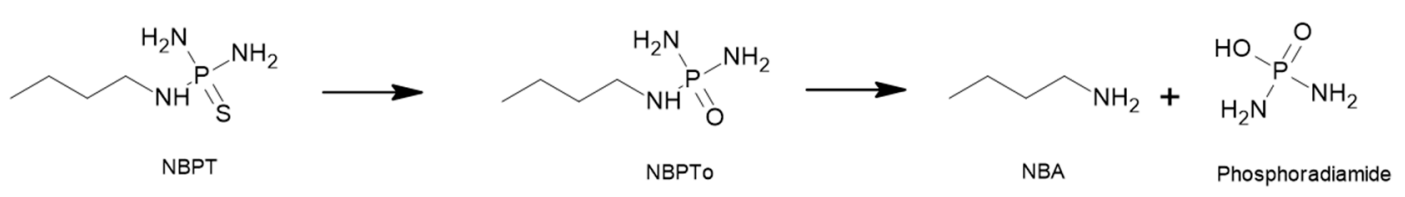

Figure 2. Breakdown products of N-(n-butyl) thiophosphoric triamide (NBPT).

The European Chemicals Agency (ECHA) has stated that NBPT has a DT 50 (t1/2) of 26-30 d at $12-25^{\circ} \mathrm{C}$ in soil and a $\mathrm{DT}_{50}$ of $15 \mathrm{~d}$ in freshwater. In freshwater sediment, NBPT is cited to persist longer and has a $\mathrm{DT}_{50}$ of 4.5 months at $25^{\circ} \mathrm{C}$ [63]. The $\log \mathrm{K}_{\mathrm{oc}}$ (soil adsorption coefficient) value of NBPT was estimated to be below 1.25. Low $\log \mathrm{K}_{\mathrm{oc}}$ values are considered an environmental risk due to their potential to leach from the soil and pollute groundwater. NBPT falls within the log $\mathrm{K}_{\mathrm{ow}}$ range of 1-2 indicating that it is 'mobile to highly mobile', indicating it could potentially be leached from the soil and pose a threat as a groundwater pollutant if present over the recommended usage levels [64]. However, NBPT is applied at low levels when used in conjunction with urea fertilizer i.e., $50 \mathrm{~g} / \mathrm{ha}$ per application, in addition, it breaks down rapidly in acidic soils [56], making it unlikely to become an environmental pollutant at recommended levels of use. The estimated bioconcentration factor (BCF) for NBPT is $3.162 \mathrm{lipid} / \mathrm{kg}$ ww (wet weight). NBPT is not expected, therefore, to bioaccumulate in fish or the food chain as it is well below the REACH BCF threshold value of $>2000 \mathrm{~L} / \mathrm{kg} / \mathrm{bw}$ (body weight).

It is important to assess the toxicology of each individual inhibitor in order to evaluate their chemical safety. A summary of available toxicology data for NBPT is shown below (Table 4), which contains data from three separate toxicology studies conducted by The European Chemicals Agency (ECHA) in 1996, and The National Australian Industrial Chemicals Notification and Assessment Scheme (NICNAS) in 1997 and 2011. 
Table 4. Summary of available NBPT toxicology.

\begin{tabular}{|c|c|c|c|c|c|c|c|c|}
\hline Compound & Animal & Parameter & Exposure Type & $\begin{array}{c}\text { Method of } \\
\text { Administration }\end{array}$ & $\begin{array}{c}\text { Dose } \\
(\mathrm{mg} / \mathrm{kg} / \mathrm{bw})\end{array}$ & Sex & Toxicology Results and Clinical Observations & References \\
\hline \multirow{7}{*}{ NBPT } & Rat & $\mathrm{LD}_{50}$ & Acute exposure & $\begin{array}{c}\text { Oral } \\
\text { Dermal }\end{array}$ & 2000 & Male/Female & $\begin{array}{l}\text { Low toxicity via oral and dermal exposure, LD50 in rats } \\
\text { exceeded } 2000 \mathrm{mg} / \mathrm{kg} / \mathrm{bw}\end{array}$ & [65] \\
\hline & Guinea Pig & Skin Sensitizer & Acute exposure & $\begin{array}{l}\text { intradermal } \\
\text { injections }\end{array}$ & - & Male/Female & Not a skin sensitizer. & [55] \\
\hline & Rabbit & Ocular toxicity & Acute exposure & Ocular & $\begin{array}{c}0.1 \mathrm{~mL} \text { of test } \\
\text { material } \\
\text { (AGROTAIN, } \\
25 \% \text { NBPT) } \\
\end{array}$ & Male/Female & $\begin{array}{l}\text { Severe eye irritant with irritation observed on the } \\
\text { conjunctiva, cornea, and iris. }\end{array}$ & [65] \\
\hline & Rabbit & Ocular toxicity & Acute exposure & Ocular & $\begin{array}{l}0.1 \mathrm{~mL} \text { of NBPT } \\
\text { (white powder) }\end{array}$ & Male/Female & $\begin{array}{l}\text { Irreversible eye damage. Scattered or subtle corneal } \\
\text { opacity and vascularization noted in the treated eye. } \\
\text { NBPT considered an irritant with the potential to cause } \\
\text { severe of eye damage. }\end{array}$ & [55] \\
\hline & \multirow{3}{*}{ Rat } & Neurotoxicity & $\begin{array}{l}\text { Repeat exposure } \\
\quad(13 \text { weeks) }\end{array}$ & Oral & $\begin{array}{l}200,1000 \text { and } \\
5000\end{array}$ & $\begin{array}{l}\text { Male } \\
\text { Female }\end{array}$ & $\begin{array}{l}\text { Decreased food utilization and lower body weights noted } \\
\text { at } 5000 \mathrm{mg} / \mathrm{kg} \text { bw. neurotoxic study observed decreased } \\
\text { gripping strength in } 5000 \mathrm{mg} / \mathrm{kg} \text { bw male. No effect } \\
\text { observed during ophthalmoscopic examination. } \\
\text { Decreased food utilization and lower body weights noted } \\
\text { at } 5000 \mathrm{mg} / \mathrm{kg} \text { bw. Decreased gripping strength and } \\
\text { hunched posture observed in } 5000 \mathrm{mg} / \mathrm{kg} \text { bw females. } \\
\text { No effect observed during ophthalmoscopic examination. }\end{array}$ & \multirow{3}{*}{ [53] } \\
\hline & & Hemotology & $\begin{array}{l}\text { Repeat exposure } \\
\quad(13 \text { weeks) }\end{array}$ & Oral & $\begin{array}{l}\text { 200, } 1000 \text { and } \\
5000\end{array}$ & Female & $\begin{array}{c}\text { At } 5000 \mathrm{mg} / \mathrm{kg} \text { bw increase lymphocyte counts were } \\
\text { observed which resulted in significantly lower white } \\
\text { blood cell counts. Alanine transaminase (ALT) levels and } \\
\text { aspartate aminotransferase (AST) at } 500 \text { and } 1000 \mathrm{mg} / \mathrm{kg} \\
\text { bw decreased } \\
\text { At } 5000 \mathrm{mg} / \mathrm{kg} \text { bw platelets, were significantly increased. } \\
\text { Alanine transaminase (ALT) levels and Aspartate } \\
\text { Aminotransferase (AST) at } 500 \text { and } 1000 \mathrm{mg} / \mathrm{kg} \mathrm{bw} \\
\text { decreased. Phosphorus levels significantly decreased at } \\
200 \text { and } 1000 \mathrm{mg} / \mathrm{kg} \text { bw. }\end{array}$ & \\
\hline & & Organ toxcicity & $\begin{array}{l}\text { Repeat exposure } \\
\quad(13 \text { weeks })\end{array}$ & Oral & $\begin{array}{l}200,1000 \text { and } \\
5000\end{array}$ & Female & $\begin{array}{c}\text { Increase in liver weights at } 5000 \mathrm{mg} / \mathrm{kg} \text { bw. Minimal } \\
\text { centrilobular hepatocyte hypertrophy at } 5000 \mathrm{mg} / \mathrm{kg} \mathrm{bw} \text {. } \\
\text { Increase in uterine weights at } 5000 \mathrm{mg} / \mathrm{kg} \text { bw. Increased } \\
\text { in uterine fluid and luminal distension at all dosages. } \\
\text { Minimal centrilobular hepatocyte hypertrophy at } 5000 \\
\mathrm{mg} / \mathrm{kg} \text { bw. Increased incidence of foci mineralization in } \\
\text { kidney at } 5000 \mathrm{mg} / \mathrm{kg} \mathrm{bw}\end{array}$ & \\
\hline
\end{tabular}


Table 4. Cont

\begin{tabular}{|c|c|c|c|c|c|c|c|c|}
\hline Compound & Animal & Parameter & Exposure Type & $\begin{array}{c}\text { Method of } \\
\text { Administration }\end{array}$ & $\begin{array}{c}\text { Dose } \\
(\mathrm{mg} / \mathrm{kg} / \mathrm{bw})\end{array}$ & Sex & Toxicology Results and Clinical Observations & References \\
\hline & \multirow{3}{*}{ Rat } & Neurotoxicity & $\begin{array}{l}\text { Repeat exposure } \\
\quad(15 \mathrm{~d})\end{array}$ & Oral & $\begin{array}{l}0,250,500,1000 \\
\text { and } 2000\end{array}$ & Male/Female & $\begin{array}{l}\text { Decreases in cholinesterase levels observed in brain tissue } \\
\text { and erythrocytes the at } 500,1000 \text { and } 2000 \mathrm{mg} / \mathrm{kg} \text { bw }\end{array}$ & \multirow{3}{*}{ [65] } \\
\hline & & Hematology & $\begin{array}{l}\text { Repeat exposure } \\
\quad(15 \mathrm{~d})\end{array}$ & Oral & $\begin{array}{l}0,250,500,1000 \\
\quad \text { and } 2000\end{array}$ & $\begin{array}{l}\text { Male } \\
\text { Female }\end{array}$ & $\begin{array}{c}\text { Liver damage observed with no chlorosis at } 500 \mathrm{mg} / \mathrm{kg} \\
\text { bw, no change in liver weight. At } 500-2000 \mathrm{mg} / \mathrm{kg} \text { bw } \\
\text { decreased triglycerides observed. } \\
\text { Liver damage observed with no chorosis at } 500 \\
\mathrm{mg} / \mathrm{kg} / \mathrm{bw} \text { no change in liver weight. At } 500 \mathrm{mg} / \mathrm{kg} / \mathrm{bw} \\
\text { decreased blood urea \& total cholesterol observed. }\end{array}$ & \\
\hline & & Organ toxcicity & $\begin{array}{l}\text { Repeat exposure } \\
\quad(15 \mathrm{~d})\end{array}$ & Oral & $\begin{array}{l}0,250,500,1000 \\
\text { and } 2000\end{array}$ & Male/Female & $\begin{array}{l}\text { Spleen: body weight ratio affected at } 500 \mathrm{mg} / \mathrm{kg} / \mathrm{bw} \text { and } \\
\text { above. }\end{array}$ & \\
\hline & \multirow{3}{*}{ Rat } & $\begin{array}{l}\text { Reproductive } \\
\text { toxicity }\end{array}$ & $\begin{array}{c}\text { Repeat exposure } \\
\text { (over two } \\
\text { generations) }\end{array}$ & Oral & $\begin{array}{l}0,200,800 \text { and } \\
3200\end{array}$ & $\begin{array}{l}\text { Male } \\
\text { Female }\end{array}$ & $\begin{array}{c}\text { Abnormalities in sperm counts at } 84 \mathrm{mg} / \mathrm{kg} \text { bw/day }(\mathrm{d}) \text {, } \\
\text { male rats exhibited epididymal lesions. The } \\
\text { No-observed-adverse-effect level (NOAEL) is } 21 \mathrm{mg} / \mathrm{kg} \\
\mathrm{bw} / \mathrm{d} \text {. } \\
\text { Increases in uterine weight at } 88 \mathrm{mg} / \mathrm{kg} \text { bw/d. NOAEL } \\
\text { females } 17 \mathrm{mg} / \mathrm{kg} \text { bw/d. NBPT meets the requirements to } \\
\text { be classified as a category three reproductive toxin. }\end{array}$ & \multirow{3}{*}{ [55] } \\
\hline & & Neurotoxicity & $\begin{array}{c}\text { Repeat exposure } \\
\text { (over two } \\
\text { generations) }\end{array}$ & Oral & $\begin{array}{l}0,200,800 \text { and } \\
3200\end{array}$ & $\begin{array}{l}\text { Male } \\
\text { Female }\end{array}$ & $\begin{array}{l}\text { Decreased erythrocyte cholinesterase levels at } 800 \text { and } \\
3200 \mathrm{mg} / \mathrm{kg} / \mathrm{bw} \text {. NOAEL males } 74 \mathrm{mg} / \mathrm{kg} \text { bw/d. based on } \\
\text { neurobehavioral changes. } \\
\text { Decreased erythrocyte cholinesterase levels at } 800 \text { and } \\
3200 \mathrm{mg} / \mathrm{kg} / \mathrm{bw} \text {. }\end{array}$ & \\
\hline & & Hemotology & $\begin{array}{c}\text { Repeat exposure } \\
\text { (over two } \\
\text { generations) }\end{array}$ & Oral & $\begin{array}{l}0,200,800 \text { and } \\
3200\end{array}$ & $\begin{array}{l}\text { Male } \\
\text { Female }\end{array}$ & $\begin{array}{c}\text { Effects on the liver and changes in hematology indicate a } \\
\text { lowest-observed-adverse-effect level LOAEL of } \\
377 \mathrm{mg} / \mathrm{kg} \mathrm{bw} / \mathrm{d} \text {. } \\
\text { LOAEL for females } 17 \mathrm{mg} / \mathrm{kg} \text { bw/d due to uterine } \\
\text { changes. }\end{array}$ & \\
\hline
\end{tabular}


In summary, NBPT was found not to be toxic via dermal or oral exposure, as the average $\mathrm{LD}_{50}$ in rats exceeded $2000 \mathrm{mg} / \mathrm{kg}$ body weight. To put this in perspective, the highest permitted level of NBPT allowed is $2000 \mathrm{mg} / \mathrm{kg}$ urea fertilizer $[9,66]$. NBPT caused some minor and reversible skin irritation in rabbits; however, skin irritation effects were below hazardous classification. NICNAS toxicology studies concluded that NBPT is of low acute toxicity, is not a skin sensitizer, and is not genotoxic [55]. NBPT meets the criteria to be considered an irritant and is classed as risk phase (R41) under the EU Dangerous Substances Directive (67/548/EEC), which indicates it is a risk for severe eye damage [55,65]. When directly consumed NBPT was found to cause significant reproductive changes in both male and female rats. NOAEL in males and females were found to be $21 \mathrm{mg} / \mathrm{kg} \mathrm{bw} / \mathrm{d}$ and $17 \mathrm{mg} / \mathrm{kg} \mathrm{bw} / \mathrm{d}$, respectively. The NOAEL value for reproductive toxicity is $17 \mathrm{mg} / \mathrm{kg}$ bw/d. Based on these results, NBPT meets the requirements for classification as a category three reproductive toxin as well as causing possible harm to fertility [55].

However, as NBPT utilized in commercial fertilizer, the finished product by regulation can have no more than $0.2 \%(w / w)$ on a urea-N basis. For comparison with analytical grade NBPT which is typically in the region of $98 \%$ purity. The levels present in commercial fertilizer are 1065 times less concentrated in the case of $46 \% \mathrm{~N}$ urea when treated at the maximum regulatory level making adverse affects from the use of these products unlikely. Indeed, the 2011 NICNAS report also concluded that the exposure during the application of fertilizer products by agricultural workers is minimal. The study reached this conclusion based on a calculation of the likely margin of exposure (MOE) (no-observed-adverse-effect level (NOEAL)/estimated exposure dose for NBPT). MOE is used to assess risk from chemical exposure. NBPT was found to have a low MOE, therefore any risks to fertility through the use of NBPT containing products is likely minimal [55].

Hematology results, at $500 \mathrm{mg} / \mathrm{kg} / \mathrm{d}$, revealed liver damage (without chlorosis) however no changes in liver weights were recorded [65]. The ECHA study also found Alanine transaminase (ALT) levels increased in males exposed orally to 500 and $1000 \mathrm{mg} / \mathrm{kg}$, indicating possible damage to the liver. This is in agreement with the NICAS 1997 report, which recorded liver damages in animals exposed to NBPT at this concentration [53]. NICNAS (2011) found that effects on the liver and changes in hematology in males had a NOAEL of $377 \mathrm{mg} / \mathrm{kg}$ bw/d. The NOAEL for the female test group was not determined, but the study stated that the LOAEL for females was determined to be $17 \mathrm{mg} / \mathrm{kg}$ bw/d due to uterine changes [55]. Decreases in the cholinesterase levels in brains and erythrocytes were observed in the test groups, exposed orally to 500,1000, and $2000 \mathrm{mg} / \mathrm{kg}$ bw. Cholinesterase is vital for the breakdown of the neurotransmitter, acetylcholine, which stimulates post-synaptic nerves, muscles, and endocrine glands. Chemicals that inhibit cholinesterase are considered neurotoxic. NICNAS (2011) reported decreased erythrocyte cholinesterase levels in rats in both high-dose groups exposed orally to 800 and $3200 \mathrm{mg} / \mathrm{kg}$ NBPT over two generations. When combining both the 1997 and 2011 repeat dose studies for NBPT, NICNAS concluded that the NOAEL for males is $74 \mathrm{mg} / \mathrm{kg}$ bw/d according to neurobehavioral changes observed [55,65]. Biochemical analysis demonstrated decreased levels of aspartate aminotransferase (AST) and alanine aminotransferase (ALT), at $5000 \mathrm{mg} / \mathrm{kg}$ bw. Both are valuable biomarkers that indicate liver disease when elevated. Little is known about lower than normal or decreased levels of AST and ALT. However, lower than normal ALT levels have been associated with increased incidences of mortality, especially in elderly patients [67]. Decreased AST levels were also noted in the male medium $1000 \mathrm{mg} / \mathrm{kg}$ dosage group. The NICNAS 1997 report concluded that when NBPT is used in conjunction with urea fertilizers, it is present in extremely low quantities (approximately $0.2 \%(w / w)$ urea), and should, therefore, pose no significant threat to public health and safety. The report also concluded that any residual presence in food products is also expected to be negligible [65]. EU regulation No. 2003/2003 states that the maximum NBPT inhibitor content as a percentage by mass of the total nitrogen present as urea nitrogen is $0.2 \%$. It can be inferred from the NICNAS 1997 [30] report and the percentage NBPT allowable in fertilizer products that the risk of NBPT residues appearing in EU food products is negligible. 
In 2019, van de Ligt, et al. [68] conducted a 28-day study testing the milk of Holstein dairy cows fed three levels of NBPT $(1,5$ and $10 \mathrm{mg} / \mathrm{kg}$ bw). No NBPT was detected with the exception of one milk sample from a cow exposed to $10 \mathrm{mg}$ NBPT $/ \mathrm{kg}$ bw/d. However, it was detected at levels below the limit of quantification for this method ( $50 \mu \mathrm{g} / \mathrm{kg}$ ). The lowest level of $1 \mathrm{mg}$ NBPT $/ \mathrm{kg}$ bw/d feeding equates to a NBPT exposure direct consumption of urea containing $0.1 \%$ NBPT. Direct consumption of fertilizer at this level would induce urea toxicity and is extremely unlikely to occur. The study concluded that consumption of NBPT, even at exaggerated levels, is unlikely to cause residual contamination in dairy products and supports the findings of the 1997 and 2011 NICNAS reports carried out by the Australian government's national industrial chemicals notification and assessment scheme. Even the lowest exposure levels used in this study [68] are highly inflated from the perspective of good agricultural practice.

\subsection{N-(n-propyl) Thiophosphoric Triamide (NPPT)}

NPPT has gained increasing interest as a new urease inhibitor in recent years and is currently being utilized in a new commercial formulation, in conjunction with NBPT, in a product called Limus ${ }^{\circledR}$. The formula was introduced by the German company BASF and consists of approximately $25 \%$ NPPT and 75\% NBPT. Li et al. [69] conducted a 2015 study, which indicated that formulations of $25 \%$ NPPT $/ 75 \%$ NBPT and $50 \%$ NPPT $/ 50 \%$ NBPT were more successful at inhibiting soil urease than NBPT alone. This is most likely because the combination of two urease inhibitor types would inhibit a broader range of ureases present in the soil. The effects of Limus ${ }^{\circledR}$ on $\mathrm{NH}_{3}$ volatilization and $\mathrm{N}$ utilization on wheat production in northern China exhibited an $83 \%$ reduction in $\mathrm{NH}_{3}$ losses compared to unprotected urea [70]. The study also found that the application of Limus ${ }^{\circledR}$ did not significantly affect grain yield [71].

It is notable that the structure of NPPT differs from NBPT by a single methyl group (Table 3). It is therefore likely to behave similarly to NBPT in terms of mode of action, toxicity, and degradation pathways. A summary of available toxicology data for NPPT is shown in (Table 5) from studies conducted by (ECHA).

Table 5. Summary of available N-propyl- thiosphosphoric- triamide (NPPT) toxicology.

\begin{tabular}{|c|c|c|c|c|c|c|c|c|}
\hline Compound & Animal & Parameter & $\begin{array}{c}\text { Exposure } \\
\text { Type }\end{array}$ & $\begin{array}{c}\text { Method } \\
\text { of } \\
\text { Administration }\end{array}$ & $\begin{array}{c}\text { Dose } \\
(\mathrm{mg} / \\
\mathrm{kg} / \mathrm{bw})\end{array}$ & Sex & $\begin{array}{l}\text { Toxicology } \\
\text { Results and } \\
\text { Clinical } \\
\text { Observations }\end{array}$ & References \\
\hline \multirow{4}{*}{ NPPT } & \multirow{4}{*}{ Rat } & $\mathrm{LD}_{50}$ & $\begin{array}{c}\text { Acute } \\
\text { exposure }\end{array}$ & Oral & 2000 & $\begin{array}{c}\text { Male/ } \\
\text { Female }\end{array}$ & $2000 \mathrm{mg} / \mathrm{kg}$ bw. & \multirow{4}{*}{ [57] } \\
\hline & & $\mathrm{LD}_{50}$ & $\begin{array}{l}\text { Repeat } \\
\text { exposure } \\
(28 \mathrm{~d})\end{array}$ & Oral & 200 & $\begin{array}{c}\text { Male } \\
\text { Female }\end{array}$ & $\begin{array}{c}200 \mathrm{mg} / \mathrm{kg} \text { bw. } \\
\mathrm{NOAEL} \\
18.1 \mathrm{mg} / \mathrm{kg} \text { bw } \\
200 \mathrm{mg} / \mathrm{kg} \text { bw. } \\
\mathrm{NOAEL} \\
19.8 \mathrm{mg} / \mathrm{kg} \text { bw. }\end{array}$ & \\
\hline & & $\mathrm{LD}_{50}$ & $\begin{array}{c}\text { Acute } \\
\text { exposure }\end{array}$ & Dermal & 2000 & $\begin{array}{c}\text { Male/ } \\
\text { Female }\end{array}$ & $2000 \mathrm{mg} / \mathrm{kg}$ bw. & \\
\hline & & $\begin{array}{l}\text { Developmental } \\
\text { toxicity }\end{array}$ & $\begin{array}{l}\text { Repeat } \\
\text { Exposure }\end{array}$ & Oral & 100 & Female & $\begin{array}{c}\text { NOAEL } \\
100 \mathrm{mg} / \mathrm{kg} \text { bw. }\end{array}$ & \\
\hline
\end{tabular}

NPPT is described under classification, labelling, and packaging (CLP) criteria to cause harm if ingested and may cause skin allergies [57]. NPPT was not found to be a skin sensitizer and is classified, under REACH registration as a severe eye irritant. The results of a 28-day study did not suggest any effects from exposure to NPPT on reproductive organs, however, due to ECHA's 'read-across' approach to NBPT, as they are structurally similar, NPPT is suspected to be a reproductive toxin with the potential to cause harm to fertility and/or the unborn child. Studies on developmental toxicity in rats via oral administration of NPPT found the NOAEL to be $100 \mathrm{mg} / \mathrm{kg}$ bw/d [57]. 


\subsection{N-(2-nitrophenyl) Phosphoric Triamide (2-NPT)}

2-NPT is a relatively new urease inhibitor, which was developed by the SKW Company in the 2000s and has shown much promise in reducing $\mathrm{NH}_{3}$ volatilization $[9,72]$. The mechanism of action of 2-NPT is thought to be similar to NBPT as it blocks the urease enzyme active site and is, therefore, considered a urea analog-type inhibitor (Table 2). The advantages of 2-NPT include more robust stability than NBPT under high-temperature conditions and it is considered non-toxic to soil bacteria [72]. A 2014 study found that 2-NPT reduced $\mathrm{NH}_{3}$ emissions by 48 to $89 \%$ compared to unprotected urea [73]. These findings are supported by the results of a previous 2010 study which observed 49 to $75 \%$ reductions in $\mathrm{NH}_{3}$ emissions compared to unprotected urea, when used on spring grass [74].

The physicochemical properties of 2-NPT are described in (Table 3). The compound is predominantly polar in nature. 2-NPT is expected to be metabolized, in vivo, via hydroxylation of $\mathrm{N}$ and $\mathrm{C}$ atoms, which may be followed by conjugation. Due to its high water solubility and relatively low molecular weight, it is expected that, if ingested, the metabolites of 2-NPT will be excreted primarily in the urine [58]. A summary for the available toxicology data for 2-NPT is shown below (Table 6) and contains data from toxicology studies conducted by ECHA.

In summary, animal studies indicated that 2-NPT is not classifiable as a skin or eye irritant, skin sensitizer, or genotoxin. Currently, no studies have been conducted on endocrine disruption ability, carcinogenicity, or inhalation toxicity [58]. 
Table 6. Summary of available 2-NPT toxicology.

\begin{tabular}{|c|c|c|c|c|c|c|c|c|}
\hline Compound & Animal & Parameter & Exposure Type & $\begin{array}{c}\text { Method of } \\
\text { Administration }\end{array}$ & $\begin{array}{c}\text { Dose } \\
(\mathrm{mg} / \mathrm{kg} \mathrm{bw})\end{array}$ & Sex & $\begin{array}{c}\text { Toxicology Results and CLINICAL } \\
\text { OBSERVATIONS }\end{array}$ & References \\
\hline \multirow{5}{*}{ 2-NPT } & Rat & $\mathrm{LD}_{50}$ & Acute exposure & $\begin{array}{c}\text { Oral } \\
\text { Dermal }\end{array}$ & $>2000$ & Male/Female & $>2000 \mathrm{mg} / \mathrm{kg}$ bw. & \multirow{5}{*}{ [58] } \\
\hline & Rat & Reproductive toxicity & $\begin{array}{l}\text { Repeat } \\
\text { Exposure }\end{array}$ & Oral & $0,45,135,450$ & Male/Female & $\begin{array}{l}\text { NOAEL for parental animals is } 45 \mathrm{mg} / \mathrm{kg} \\
\text { bw/d. NOAEL for reproductive toxicity } \\
\text { and toxicity to first-generation pups is } \\
135 \mathrm{mg} / \mathrm{kg} \text { bw. }\end{array}$ & \\
\hline & Rat & Reproductive toxicity & $\begin{array}{c}\text { Repeat } \\
\text { Exposure }(28 \mathrm{~d})\end{array}$ & Oral & $0,30,100$ and 300 & Male & $\begin{array}{l}\text { NOAEL } 30 \mathrm{mg} / \mathrm{kg} \text { bw. At } 300 \mathrm{mg} / \mathrm{kg} / \mathrm{bw} \\
\text { increased leucocyte count and decreased } \\
\text { organ weights for testes and epididymides. } \\
\text { Irreversible effects to the micro-orchidia } \\
\text { and epididymides. Damage to the testes } \\
\text { across all dose groups and high dose } \\
\text { groups completely void of spermatozoa. }\end{array}$ & \\
\hline & Rat & Hemotology & $\begin{array}{c}\text { Repeat } \\
\text { Exposure }(28 \mathrm{~d})\end{array}$ & Oral & $0,30,100$ and 300 & Male/Female & $\begin{array}{l}\text { Decreased levels of alkaline phosphatase } \\
\text { and aspartate aminotransferase (AST) at } \\
\text { high doses. }\end{array}$ & \\
\hline & Rat & Organ toxicity & $\begin{array}{c}\text { Repeat } \\
\text { Exposure }(28 \mathrm{~d})\end{array}$ & Oral & $0,30,100$ and 300 & Male & $\begin{array}{l}\text { Increased spleen weights. } \\
\text { Dose-dependent kidney damage with } \\
\text { degenerated tubular epithelium in the } \\
\text { medulla of the kidneys observed at high } \\
\text { doses. Dose dependent urine glucose } \\
\text { increase. Discoloration of urine on day of } \\
\text { administration. } \\
\text { Dose-dependent kidney damage with } \\
\text { degenerated tubular epithelium in the } \\
\text { medulla of the kidneys at high doses. } \\
\text { Dose-dependent urine glucose increase. } \\
\text { Discoloration of urine on day of } \\
\text { administration. }\end{array}$ & \\
\hline
\end{tabular}




\section{Nitrification Inhibitors Types, Mode of Action, and Their Role in GHG Reduction}

Nitrification inhibitors are a class of chemicals used to slow down the nitrification process by inhibiting nitrifying bacteria that produce the enzyme ammonia monooxygenase (AMO), hydroxylamine oxidoreductase (HAO) and nitric oxide reductase (NOR). Nitrification occurs in two steps the first step involves the oxidation of $\mathrm{NH}_{4}{ }^{+}$to hydroxylamine $\left(\mathrm{NH}_{2} \mathrm{OH}\right)$ via the enzyme AMO. $\mathrm{NH}_{2} \mathrm{OH}$ is then subsequently converted to $\mathrm{NO}_{2}{ }^{-}$via the enzyme HAO. During the second step of nitrification, $\mathrm{NO}_{2}{ }^{-}$is oxidized to $\mathrm{NO}_{3}{ }^{-}$via the enzyme NOR. The $\mathrm{NO}_{3}{ }^{-}$produced during the nitrification process can result in $\mathrm{N}$ losses due to leaching or denitrification ${ }^{-}$. The mode of action for most nitrification inhibitors is inhibition AMO during the first step of nitrification [45].

Nitrification inhibitors have gained interest as a possible mitigation strategy for lowering $\mathrm{N}_{2} \mathrm{O}$ emissions as well as reducing water pollution associated with use of fertilizers. Some examples of nitrification inhibitors include DCD and DMPP, thiourea, carbon sulfide (CS2), thioethers, ethylene: C2-H2, 2-ethynylpyridine, 3-amino-1,2,4-triazole, N-2,5-dichlorophenyl succinamic acid (DCS), 2-amino-4-chloro-6-methyl pyrimidine (AM), nitrapyrine (NP) and ammonium thiosulphate (ATS) [11], and N-[3(5)-methyl-1H-pyrazol-1-yl) methyl] acetamide (MPA) [75].

DCD is a popular nitrification inhibitor that effectively reduces $\mathrm{N}_{2} \mathrm{O}$ emissions. Decreases in gross nitrification rates in neutral silt loam and alkaline clay by up to $57.9 \%$ and $62.4 \%$, respectively, have been achieved using DCD. With a $93.2 \%$ drop in $\mathrm{N}_{2} \mathrm{O}$ emissions from neutral silt loam and $46.8 \%$ in alkaline clay soil observed. It also reduced the amount of $\mathrm{NO}_{3}{ }^{-}$accumulation by approximately $20 \%$ in both soil types [76]. Reduction of up to $40 \%$ is $\mathrm{N}_{2} \mathrm{O}$ emission rates have also been observed in dry sandy-loam soils [77]. DCD, utilized in conjunction with urea, reduced $\mathrm{N}_{2} \mathrm{O}$ emissions by $58-78 \%$ in grassland and barley fields [78]. DCD is more effective at inhibiting nitrification and lowering $\mathrm{N}_{2} \mathrm{O}$ emissions in arable soils than in grassland soils. One study described $\mathrm{N}_{2} \mathrm{O}$ emission reductions of $81 \%$ in arable soil and $58 \%$ in grass land soil and concluded that this is likely because grassland naturally contains higher concentrations of $\mathrm{N}$ than arable soil types [79]. Although DCD was a popular nitrification inhibitor, it is disadvantaged by its high price and high dosages (15-30 kg DCD ha $\left.{ }^{-1}\right)$, as it is a relatively weak inhibitor [11]. Other disadvantages of DCD include the possibility of phytotoxicity, which often results in leaf tip scorching, and ultimately reduces the aesthetics of leafy green crops thus harming their marketability [80]. Food safety concerns were also raised when DCD was found in milk powder. This has raised concerns regarding the practice of spraying DCD on pastures in order to reduce $\mathrm{N}$ leaching [81].

\subsection{Dicyandiamide (DCD)}

$\mathrm{DCD}$ is an inorganic crystalline solid susceptible to biodegradation in soil, yielding urea, $\mathrm{CO}_{2}$, and $\mathrm{NH}_{4}{ }^{+}$. The physicochemical properties of DCD are described in (Table 3). DCD is polar, based on its $\log \mathrm{K}_{\mathrm{ow}}$ value of -1.0 [59], is highly water-soluble and can be prone to leaching from the rooting zone where it is intended to inhibit nitrification. One study conducted by Cahalan, et al. [82] tested the effect of precipitation and application rate on DCD persistence and efficacy in two Irish grassland types (cambisol and gleysol) over eight weeks at application rates of 15 or $30 \mathrm{~kg} \mathrm{DCD} \mathrm{ha}^{-1}$ during high or low precipitation. High precipitation increased DCD in leachate, with less DCD recovered from soil. Approximately $81 \%$ of DCD was degraded in cambisol and was unaffected by the rate of DCD applied. Degradation of DCD in gleysol was affected by application rate and degraded by approximately $67 \%$ at $15 \mathrm{~kg} \mathrm{DCD} \mathrm{ha}^{-1}$ and $46 \%$ when DCD was applied at $30 \mathrm{~kg}^{\mathrm{DCD}} \mathrm{ha}^{-1}$. The study found that degradation rates of DCD in soil were not related to temperature or moisture and it was hypothesized that the differences in degradation rates between cambisol and gleysol may be related to differing organic matter content and associated microbiological activity. Overall, the study observed increasing levels of precipitation correlated with higher leaching of DCD. This effect is also cited by Shepherd et al., 2012 [83].

DCD is bacteriostatic but not bactericidal and acts to inhibit the enzyme AMO [59,84]. AMO is an essential metalloenzyme of nitrifying bacteria, which catalyzes the hydrolysis of $\mathrm{NH}_{3}$ to hydroxylamine 
and functions ultimately as a substrate for $\mathrm{N}_{2} \mathrm{O}$ production. Inhibition of AMO occurs as DCD acts as a copper chelating agent and binds to copper-containing parts of the enzyme's active site [79]. Inhibition of the AMO enzyme reduces $\mathrm{N}_{2} \mathrm{O}$ emissions because the nitrification process carried out by ammonia-oxidizing bacteria (AOB) is slowed [24,85]. The inhibitory effect causes $\mathrm{N}$ to remain in its $\mathrm{NH}_{4}{ }^{+}$form longer and results in less $\mathrm{NO}_{2}{ }^{-}$and $\mathrm{NO}_{3}{ }^{-}$production. This ultimately reduces $\mathrm{N}$ loss via leaching and atmospheric loss of $\mathrm{N}$ as $\mathrm{N}_{2} \mathrm{O}$. Leaching is prevented as $\mathrm{NH}_{4}{ }^{+}$is positively charged and can better bind to negatively charged soil particles than $\mathrm{NO}_{3}{ }^{-}$, which is repelled, and is, therefore, prone to leaching [86]. This mode of action makes DCD an attractive mitigation tool for reduction of air and waterway pollution $[24,87]$. In pure nitromonas cultures, DCD exhibits inhibition at concentrations of $200 \mathrm{mg} \mathrm{kg}^{1}$; in contrast, under these conditions, the nitrification inhibitor nitrapyrin only requires $1 \mathrm{mg} \mathrm{kg}^{1}$.

In soil, approximately 10 to $50 \mathrm{mg} \mathrm{kg}^{1}$ are required for the inhibitory effects of DCD inhibition and usually last $4-8$ weeks depending on environmental conditions [88]. DCD is a REACH registered substance. Toxicology tests carried out by ECHA indicate that DCD is virtually non-toxic. A summary of the available toxicology data for DCD is shown in (Table 7).

The compound is not considered to be a skin or eye irritant or sensitizer. Repeat exposure toxicity tests for DCD concluded that the NOAEL is greater than $24,000 \mathrm{mg} / \mathrm{kg}$ as no clinical effects were observed. No mutagenic effects were observed for DCD.

Environmental tests on DCD indicated that the substance is abiotically stable, highly water-soluble, and not readily biodegradable in water. However, it does biodegrade in soil via biotic and abiotic mechanisms. The $\mathrm{DT}_{50}$ of DCD in surface water is $>1000 \mathrm{~d}$ and $\mathrm{pH}$ has little effect on the hydrolysis of the compound $[59,89]$. Although ultimately DCD degrades to form relatively benign compounds such as carbon dioxide, $\mathrm{H}_{2} \mathrm{O}$, and $\mathrm{NH}_{3}$ [90], caution should be exercised when used near water bodies as DCD may be a potential stressor to aquatic environments. DCD may interfere with aquatic nitrification processes leading to a toxic build-up $\mathrm{NH}_{3}$, which is harmful to aquatic life [91]. 
Table 7. Summary of available dicyandiamide (DCD) toxicology.

\begin{tabular}{|c|c|c|c|c|c|c|c|c|}
\hline Compound & Animal & Parameter & Exposure Type & $\begin{array}{c}\text { Method of } \\
\text { Administration }\end{array}$ & Dose (mg/kg bw) & Sex & $\begin{array}{l}\text { Toxicology Results and } \\
\text { Clinical Observations }\end{array}$ & References \\
\hline \multirow{5}{*}{ DCD } & Rat & $\mathrm{LD}_{50}$ & Acute exposure & Oral & 10,000 & Male/Female & $10,000 \mathrm{mg} / \mathrm{kg} \mathrm{bw}$. & \multirow{5}{*}{ [59] } \\
\hline & Rat & $\mathrm{LD}_{50}$ & Acute exposure & Inhalation & $259 \mathrm{mg} / \mathrm{m}^{3}$ & Male/Female & $259 \mathrm{mg} / \mathrm{m}^{3}$ & \\
\hline & Rat & $\mathrm{LD}_{50}$ & Acute exposure & Dermal & 2000 & Male/Female & 2000 mg/kg bw. & \\
\hline & Rat & $\begin{array}{l}\text { Reproductive } \\
\text { toxicity }\end{array}$ & Repeat exposure & Oral & $0,30,100$ and 300 & Male & $\begin{array}{l}\text { NOEAL for Reproductive toxicity } \\
15,000 \mathrm{mg} / \mathrm{kg} \text { bw } \\
\text { NOEAL for Reproductive toxicity } \\
15,000 \mathrm{mg} / \mathrm{kg} \text { bw. Significantly lower } \\
\text { body weights in the high dose females } \\
\text { exposed to } 50,000 \mathrm{mg} / \mathrm{kg} \text { and slightly } \\
\text { lower fertility and pregnancy rates in } \\
\text { females in this group, therefore, the } \\
\text { LOAEL for reproductive toxicity is } \\
50,000 \mathrm{mg} / \mathrm{kg} \text {. }\end{array}$ & \\
\hline & Rat & $\begin{array}{c}\text { Two-year } \\
\text { carcinogenicity } \\
\text { study }\end{array}$ & $\begin{array}{l}\text { Chronic } \\
\text { exposure }\end{array}$ & Oral & Up to 50,000 & Male/Female & $\begin{array}{l}\text { No increase in tumours; } \\
\text { non-carcinogenic }\end{array}$ & \\
\hline
\end{tabular}




\subsection{Nitrapyrin}

Nitrapyrin was registered for use in the USA in 1974 and has since been a widely utilized in North America as a mitigation tool that extends the rate of ammonium conversion to nitrate during the nitrification process [92]. Nitrapyrin is predominantly utilized to produce corn but is however also used in wheat and sorghum cultivation [92]. Nitrapyrin is a volatile nitrification inhibitor that is usually utilized in conjunction with anhydrous ammonia [88]. Due to the inhibitors volatile nature and relatively high vapor pressure (Table 3), it is not very suitable for incorporation into solid fertilizers and is instead incorporated into the soil via injection usually at a depth of at least 5 to $10 \mathrm{~cm}[80,88]$. Nitrapyrin is a very selective inhibitor which inhibits nitrification due to its bactericidal effect and effects on the metabolism of nitramonas bacteria [92]. The resulting inhibition occurs at concentrations of $1.0 \mathrm{mg} \mathrm{kg}^{-1}$ in pure nitramonas cultures and at concentrations ranging from 10 to $40 \mathrm{mg} \mathrm{kg}^{-1}$ in soil [88]. Nitrapyrin is stable and persistent in cool soils but usually breaks down in warmer soils within 30 days. Its persistence in cooler soils makes it an attractive mitigation option for winter and autumn $\mathrm{N}$ fertilizer applications. Nitrapyrin is cited as an extremely effective at limiting nitrogen losses in the form of $\mathrm{NO}_{3}{ }^{-}$leaching from waterlogged soils [88]. One disadvantage of Nitrapyrin is the fact that it is considered an organic chlorine type compound increasing concerns have been raised over the fate of these compounds in the environment [80]. Nitrapyrin exhibits low acute toxicity and is not considered to be genotoxic however the substance is known to be a Category II eye irritant [92]. A summary for the available toxicology data for Nitrapyrin is shown below (Table 8) and contains data from toxicology studies conducted by ECHA. 
Table 8. Summary of available Nitrapyrin toxicology.

\begin{tabular}{|c|c|c|c|c|c|c|c|c|}
\hline Compound & Animal & Parameter & Exposure Type & $\begin{array}{c}\text { Method of } \\
\text { Administration }\end{array}$ & $\begin{array}{c}\text { Dose } \\
(\mathrm{mg} / \mathrm{kg} \mathrm{bw})\end{array}$ & Sex & $\begin{array}{l}\text { Toxicology Results and } \\
\text { Clinical Observations }\end{array}$ & References \\
\hline \multirow{8}{*}{ Nitrapyrin } & Rat & $\mathrm{LD}_{50}$ & Acute exposure & Oral & 5000 & Male/Female & $5000 \mathrm{mg} / \mathrm{kg} \mathrm{bw}$ & \multirow{8}{*}{ [32] } \\
\hline & Rat & $\mathrm{LD}_{50}$ & Acute exposure & Inhalation & $630-3510 \mathrm{mg} / \mathrm{m}^{3}$ & Male/Female & $630-3510 \mathrm{mg} / \mathrm{m}^{3}$ & \\
\hline & Rabbit & $\mathrm{LD}_{50}$ & Acute exposure & Dermal & 2000 & Male/Female & 2000 mg/kg bw. & \\
\hline & Rat & NOEAL & Repeat exposure & Oral & 5 & Male/Female & NOAEL $5 \mathrm{mg} / \mathrm{kg}$ bw/day & \\
\hline & Rabbit & NOEAL & Repeat exposure & Dermal & $2000,2.2 \mathrm{mg} / \mathrm{cm}^{2}$ & Male/Female & $\begin{array}{c}\text { Dermal NOAEL for } \\
\text { systemic effects } 1000 \mathrm{mg} / \mathrm{kg} \\
\text { bw/day, Dermal NOAEL } \\
\text { for Local effects } 2.2 \mathrm{mg} / \mathrm{cm}^{2}\end{array}$ & \\
\hline & Rat & $\begin{array}{l}\text { NOEAL } \\
\text { Reproductive } \\
\text { toxicity }\end{array}$ & Repeat exposure & Oral & 75,50 & Male/Female & $\begin{array}{l}\text { NOEAL for Reproductive } \\
\text { toxicity } 75 \mathrm{mg} / \mathrm{kg} \text { bw/day } \\
\text { NOEAL for Developmental } \\
\text { toxicity } 50 \mathrm{mg} / \mathrm{kg} \mathrm{bw} / \text { day }\end{array}$ & \\
\hline & Rat & $\begin{array}{c}\text { NOEAL } \\
\text { Neurotoxicity }\end{array}$ & Repeat exposure & Oral & 40 & Male/Female & $40 \mathrm{mg} / \mathrm{kg}$ bw/day & \\
\hline & Mouse & $\begin{array}{c}\text { NOAEL } \\
\text { carcinogenicity }\end{array}$ & Chronic exposure & Oral & 125 & Male/Female & NOAEL 125 mg/kg bw/day & \\
\hline
\end{tabular}




\subsection{3,4-Dimethylpyrazole Phosphate (DMPP)}

The nitrification inhibitor 3,4-dimethylpyrazole phosphate (DMPP) is a supposed Cu-selective metal chelators, which acts to inhibit the AMO enzyme necessary for nitrification [46]. DMPP is suitable for use in conjunction with solid, liquid fertilizer, and slurry. DMPP is a more potent inhibitor than DCD with a much lower application rate of $0.5-1.5 \mathrm{~kg} \mathrm{ha}^{-1}$; this, coupled with less mobility in soil due to sorption, gives it a number of advantages over DCD [93]. The nitrification inhibition potential for DMPP is approximately 4-10 weeks depending on climate and soil conditions [80]. The physicochemical properties of DMPP are described in Table 3. It has been extensively tested for both ecological and toxicological effects and has been approved for use [80]. Under the Globally Harmonized System of Classification (GHS), DMPP is known to cause severe eye damage (category 1) and is also known to be harmful if swallowed (category 4) [60].

\subsection{3,4-Dimethylpyrazole Succinic (DMPSA)}

DMPSA is a relatively new type of nitrification inhibitor that is more stable in basic conditions than the nitrification inhibitor DMPP due to the presence of a succinic group. The physicochemical properties of DMPSA are described in Table 3. This nitrification inhibitor is suitable for use with CAN and diammonium phosphate (DAP) [94]. Pacholski, et al. [95] found that the use of DMPSA in conjunction with urea and CAN fertilizers reduced $\mathrm{N}_{2} \mathrm{O}$ emissions by $60-90 \%$ when compared to standard untreated fertilizer. The study also found that $\mathrm{NO}_{3}{ }^{-}$was found in considerably lower amounts when DMPSA was utilized as the inhibitor successfully sustained higher levels of ammonium [94,95]. An isomeric mixture of DMPSA is registered for use in the EU, and a summary of the available toxicology data can be found below in (Table 9).

No genotoxic or sensitization were observed. However, DMPSA is considered to be an eye irritant with adverse effect observed and is classed as a Category 1 H318 under GHS [96]. 
Table 9. Summary of available 4,5-dimethylpyrazole-1-yl-succinic acid (DMPSA) toxicology.

\begin{tabular}{|c|c|c|c|c|c|c|c|c|}
\hline Compound & Animal & Parameter & Exposure Type & $\begin{array}{c}\text { Method of } \\
\text { Administration }\end{array}$ & $\begin{array}{c}\text { Dose } \\
(\mathrm{mg} / \mathrm{kg} \mathrm{bw})\end{array}$ & Sex & $\begin{array}{l}\text { Toxicology Results and } \\
\text { Clinical Observations }\end{array}$ & References \\
\hline \multirow{4}{*}{ DMPSA } & Rat & $\mathrm{LD}_{50}$ & Acute exposure & Oral & $>2000$ & Male/Female & $>2000 \mathrm{mg} / \mathrm{kg} \mathrm{bw}$ & \multirow{4}{*}[32,96]{} \\
\hline & Rat & $\mathrm{LD}_{50}$ & Acute exposure & Dermal & $>2000$ & Male/Female & $>2000 \mathrm{mg} / \mathrm{kg}$ bw. & \\
\hline & Rat & NOEAL & Repeat exposure & Oral & $\geq 1000$ & Male/Female & NOAEL $\geq 1000 \mathrm{mg} / \mathrm{kg}$ bw/day & \\
\hline & Rat & $\begin{array}{l}\text { NOEAL } \\
\text { Reproductive } \\
\text { toxicity }\end{array}$ & Repeat exposure & Oral & 1000 & Male/Female & $\begin{array}{c}\text { NOEAL for Reproductive toxicity } \\
1000 \mathrm{mg} / \mathrm{kg} \mathrm{bw} / \text { day. } \\
\text { No developmental effects } \\
\text { were observed. }\end{array}$ & \\
\hline
\end{tabular}




\section{Inhibitor Plant Uptake Potential}

\subsection{Urease Inhibitor Plant Uptake}

Urease inhibitors added to $\mathrm{N}$ fertilizers can retain $\mathrm{N}$ in its $\mathrm{NH}_{4}{ }^{+}$form, resulting in longer uptake of $\mathrm{NH}_{4}{ }^{+}$, which in turn provides more opportunity for $\mathrm{N}$ to be fixed or immobilized in organic or mineral components of soil. Evidence of this has been cited by both Soliman and Monem [97] and $\mathrm{Xu}$ et al. [98]. Increases in available $\mathrm{N}$ derived from fertilizers in the presence of urease and nitrification inhibitors have also been cited [99]. There is some evidence that NBPT may be taken up by plant roots and this was demonstrated in maize seedlings by limited net urea uptake and reduced ureic-N accumulation [100]. Cruchaga et al. [101] also detected NBPT in pea and spinach plant tissues treated with $100 \mu \mathrm{M}$ concentrations. The study found that NBPT absorbed by plants caused inhibition of urease activity in pea leaf and roots, as a result of which, urea build-up was observed and was responsible for necrosis of the plant at leaf margins. Earlier studies also found that NBPT utilized at high concentrations of urea $(0.5 \% w / w)$, and concentrations of $10 \mu \mathrm{g} / \mathrm{g}$ of soil was associated with leaf tip scorch. This effect is hypothesized to be dose-dependent $[48,102]$ and the resulting leaf tip scorch is thought to be caused by a toxic build-up of urea at the leaf tip rather than a cytotoxic effect exerted by the NBPT itself. However, it is unlikely that plants will be exposed to such high levels of NBPT, as the EU maximum inhibitor augmentation for NBPT is $0.02 \%(w / w)$ urea. Reports on the capacity of plants to take up NBPT, with consequences on endogenous urease and plant metabolism, have also been cited by Ariz et al. [103]. Cruchaga et al. [101], also found that NBPT taken up by pea and spinach roots is translocated to the leaves; consequently, NBPT could potentially inhibit the activity of endogenous leaf and root urease. The fact that plants can assimilate NBPT is further evidenced by the compound's relatively low octanol-water partition coefficient value $\left(\mathrm{K}_{\mathrm{ow}}\right)$ i.e., the tendency of a compound to move between aqueous and lipid phases. NBPT has a relatively low $\mathrm{K}_{\mathrm{ow}}$ of 0.444 , which indicates that NBPT is readily soluble in water [53]. It is cited that compounds with $\mathrm{K}_{\mathrm{ow}}$ values of $\leq 2$ possess the ability for translocation in plant trans-vascular systems. Further studies on the uptake potential of NBPT by plants fertilized with NBPT-treated urea would be beneficial in assessing possible food chain entry points via grazing animals [104].

\subsection{Nitrification Inhibitor Plant Uptake}

The nitrification inhibitor DCD possesses a $\mathrm{K}_{\mathrm{ow}}$ value of -1 indicating that in theory, it should be possible for translocation of DCD in the trans-vascular systems of plants. A 2018 study found that plants have the capacity to take up DMPP and DMPSA and these were subsequently found in plant tissues [81]. The study was conducted on clover plants and found that DMPP accumulated in the leaves of the clover where it caused necrosis on the leaf margins. In contrast, DMPSA usually accumulated in the roots and was deemed to be innocuous. Although both inhibitors posed an extremely low risk of phytotoxicity, this was observed only at DMPP concentrations for of $100 \mathrm{mg} / \mathrm{kg}$ soil, which is much higher than the estimated maximum amount used in agriculture $(0.5 \mathrm{mg} / \mathrm{kg}$ soil $)$. DMPSA did not produce phytotoxicity even at dosage levels of $100 \mathrm{mg} / \mathrm{kg}$ soil [81].

\section{Survival of Inhibitor Compounds in Rumen}

\subsection{Survival of Urease Inhibitors in the Rumen}

There are currently few studies available on the survival of urease inhibitors in bovine rumen. Studies conducted on the ovine rumen have indicated that NBPT can temporarily inhibit microbial urease activity, although, over time, rumen microflora adapted to NBPT administration. At high doses $(88.89 \mathrm{mg} / \mathrm{kg} \mathrm{bw} / \mathrm{d})$, NBPT caused a $77 \%$ inhibition of ruminal urease. The study also stated that at these high doses, negative post-absorptive effects may occur, which could affect ruminal nitrogen metabolism, due to metabolites produced from NBPT. It is, however, inconceivable that the rumen 
should be exposed to this level of NBPT through ingestion of fertilizer while grazing, as the dose administered was much higher than the maximum allowable inhibitor content.

Rumen $\mathrm{pH}$ can vary depending on diet; however, it typically ranges from 6.2 and 7.2 [105]. Engel et al. 2015 [56] investigated the effect of $\mathrm{pH}$ on NBPT degradation in soil. The study tested both chemical buffer incubations at $\mathrm{pH}(4.0,5.0,6.0$, and 7.2) and soil incubations at $\mathrm{pH}(5.1,6.1,7.6$, and 8.2). The study concluded that degradation of NBPT and NBPTo in acidic to slightly alkaline environments (pH 5.1-7.6) most likely occurs by chemical hydrolysis and that degradation via microbial action would be dominant in alkaline environments ( $\mathrm{pH}$ 8.2). Based on such findings, chemical hydrolysis mechanisms would appear to be the likely degradation pathways of NBPT and NBPTo under rumen $\mathrm{pH}$ conditions.

\subsection{Survival of Nitrification Inhibitors in the Rumen}

It is important to establish whether nitrification and urease inhibitors can survive the harsh conditions of rumen digestion, should they be ingested. Research has been carried out in non-lactating, Friesian dairy cows given the nitrification inhibitor, $\mathrm{DCD}$, administered directly into the rumen or mixed with grass silage (GS). DCD recovery rates were $>80 \%$ of the daily dose in urine, and $2-10 \%$ in feces. A small fraction of DCD was unaccounted for, which was probably degraded in the rumen $[106,107]$.

Studies by Welten et al. $[107,108]$ investigated the ability of DCD to mitigate $\mathrm{N}$ losses from urine soil patches and the long-term effects of DCD exposure via oral administration over $90 \mathrm{~d}$ to dairy heifers. The studies found no significant changes in blood metabolites and most of the DCD administered was excreted in the urine. This is in agreement with the findings of Minet, et al. [109]. Only 1.2\% of DCD was excreted in milk after oral administration, which was rapidly eliminated and showed sharp declines in its concentration a few days later. After a five-day withdrawal period, DCD was not detectable. The study concluded that administration of DCD to lactating cattle resulted in low levels of chemical detection in milk [108].

The recommended rate for DCD application in New Zealand prior to 2013 was $10 \mathrm{~kg}^{\mathrm{DCD} \mathrm{ha}}{ }^{-1}$, which was broadcast-sprayed directly onto pastureland in spring and autumn [110]. This led ultimately to residual DCD contamination in dairy milk powder. Although DCD was later found to be nontoxic at the levels detected, it is a precursor chemical to melamine, which had, notoriously, been used as an adulterant in Chinese milk products and resulted in the deaths of six infants [10]. The detection of DCD even at residual levels caused a problem in the Chinese market, which was exacerbated by the fact that no MRL was in place within Chinese regulations [107]. EFSA has since introduced a tolerable daily intake (TDI) of $1 \mathrm{mg} / \mathrm{kg}$ bodyweight for DCD in food products [85].

\section{Passage of Contaminants into Milk via the Blood-Milk Barrier}

The blood-milk barrier present in the mammary gland is composed of the epithelium of the blood capillaries, which surround and supply the secretory epithelium in the mammary gland, which controls the passage of nutrients into milk. The passage of contaminants across the blood-milk barrier depends mainly on their physicochemical properties. Contaminants such as veterinary medicines, agrichemicals, mycotoxins, and radionucleotides can enter milk from the bloodstream via various mechanisms including passive diffusion and/or the ability to bind to plasma proteins.

The passage of contaminants into milk is determined by various different factors including molecular weight, lipid solubility, protein binding, degree of ionization, volume of distribution, half-life, and pKa of the contaminant. Contaminants with high molecular weights (600 Da and over), low lipid solubility, a large volume of distribution, high protein binding, and short half-lives are less likely to be transfer into milk [111].

Contaminants possessing the ability to diffuse passively across the blood-milk barrier are predominantly small, non-polar molecules; large polar molecules cannot pass the blood-milk barrier via this mechanism. In general, polar molecules have difficultly crossing phospholipid membranes and diffusion alone would occur extremely slowly. For some polar molecules, facilitative diffusion 
is sometimes possible if they can combine with membrane bound carrier proteins that shield the molecules from the hydrophobic membrane core [112].

An important factor in determining the transfer rate of contaminants from blood to milk is the blood-milk pH gradient. In healthy animals, milk usually possesses a lower $\mathrm{pH}$ than plasma. However, in diseased animals, for example animals exhibiting mastitis, changes to the $\mathrm{pH}$ gradient may result in milk having an equal or higher $\mathrm{pH}$ than plasma. This effect can alter the blood-milk barrier and increase the rate of transfer of contaminants into milk [113]. The amount of contaminant excreted into the milk is further determined by its ability to bind to plasma proteins, along with its molecular weight and lipophilicity.

To assess whether or not an individual urease inhibitor or nitrification inhibitor could impact milk quality and pose a threat to food safety, it is necessary to assess each inhibitor of interest individually, based on their physiochemical properties and their ability to withstand digestion and/or pass through the blood-milk barrier. NBPT possesses both a polar phosphoramide region and a lipophilic butyl chain allowing it to interact with both polar and non-polar phases according to its chemical structure. NBPT, however, possesses a $\log \mathrm{P}_{\mathrm{ow}}$ value of 0.444 indicating a slight preference for the lipid phase. NPPT and 2-NPT are, similarly, slightly lipophilic. In contrast, DCD has a log $\mathrm{P}_{\mathrm{ow}}$ value of -1.0 (polar) and will preferentially associate with the aqueous phase. There are some advantages to using NBPT over DCD in terms of the potential risk, albeit negligible, of transfer to food products. NBPT has a much lower application rate e.g., $0.29 \mathrm{~kg} \mathrm{ha}^{-1}$ compared to $20 \mathrm{~kg} \mathrm{ha}^{-1}$ for DCD. It also has a much shorter half-life, as low as $<1 \mathrm{~d}$ [56] compared to DCD, which is cited to have a half-life of approximately $37 \mathrm{~d}$ [23].

However, research is still needed to assess how each inhibitor will behave both within the animal and in various milk matrices [114]. It will also be important, should inhibitors be found in milk, to determine the effects of dairy processing unit operations i.e., heat treatment, membrane separation, evaporation, etc., on these compounds and their associated chemical species within different milk processing streams.

\section{Analytical Methods for the Detection of Inhibitors in Complex Milk and Environmental Matrices}

Milk contains many matrix components that can interfere with analysis, including fat, proteins, and sugars. Some level of sample preparation is nearly always required in residue analysis to eliminate matrix inference and allow adequate measurement [115]. Numerous methods have been published to analyze urease and nitrification inhibitors in various matrices, but few have been adapted to food samples (Table 10). Many methods have been developed based on HPLC-UV, but this technique is suitable for the analysis of fertilizer formulations; whereas more selective detection systems such as HPLC fluorescence or liquid chromatography coupled to tandem mass spectrometry (LC-MS/MS) are better suited for measuring the lower concentrations that might be found in food or environmental samples. 
Table 10. Analytical methods of detection of urease and nitrification inhibitors in various matrices.

\begin{tabular}{|c|c|c|c|c|c|c|c|c|}
\hline Detection Method & Target Analytes & Matrix & Sample Preparation & Column & Mobile Phase & Observed Ions & $\begin{array}{c}\text { Limit of } \\
\text { Quantification } \\
(\mathrm{LOQ})(\mu \mathrm{g} / \mathrm{kg})\end{array}$ & References \\
\hline $\begin{array}{l}\text { HPLC \& post-column } \\
\text { derivatisation with } \\
\text { fluorescence detection }\end{array}$ & NBPT, NBPTo, NBA & Soil & $\begin{array}{l}\text { Extracted with } \\
\text { deionized water \& } \\
\text { filtered }(0.22 \mu \mathrm{m})\end{array}$ & $\begin{array}{l}\text { Zorbax-Rx } \mathrm{C}_{8} \\
\text { column } \\
(4.6 \times 250 \mathrm{~mm}) \\
\end{array}$ & $40 \% \mathrm{H}_{2} \mathrm{O} 60 \% \mathrm{MeOH}$ & N/A & 1000 & [117] \\
\hline \multirow{2}{*}{ HPLC } & \multirow{2}{*}{ NBPT and NPPT } & \multirow{2}{*}{ Urea Fertilizer } & Detailed in EN 1482-1 & $\begin{array}{c}\mathrm{C}_{18} \text { Nucleosil } \\
(250 \mathrm{~mm} \times 4 \mathrm{~mm} \\
5 \mu \mathrm{m})\end{array}$ & $\mathrm{MeCN}+\mathrm{H}_{2} \mathrm{O} 10+90$ & $\mathrm{~N} / \mathrm{A}$ & $\mathrm{N} / \mathrm{A}$ & \multirow{2}{*}{ [118] } \\
\hline & & & Detailed in EN 1482-1 & $\begin{array}{l}\text { LiChroSpher } \mathrm{C}_{18} \\
(250 \mathrm{~mm} \times 4 \mathrm{~mm} \\
5 \mu \mathrm{m})\end{array}$ & $\mathrm{MeCN}+\mathrm{H}_{2} \mathrm{O} 15+85$ & $168.2 \mathrm{~m} / \mathrm{z}$ and $74 \mathrm{~m} / \mathrm{z}$ & $\mathrm{N} / \mathrm{A}$ & \\
\hline $\begin{array}{c}\text { LC-MS/MS } \\
\text { (Positive mode) }\end{array}$ & DCD and NBPT & Urea Fertilizer & $\begin{array}{l}\text { Dilution \& filtration } \\
\qquad(0.45 \mu \mathrm{m})\end{array}$ & $\begin{array}{c}\text { Obelsc-R column } \\
(4.6 \times 150 \mathrm{~mm} \\
5 \mathrm{um})\end{array}$ & $\begin{array}{c}\text { (A) } 0.05 \% \text { formic acid }+10 \mathrm{mM} \\
\text { ammonium acetate }+\mathrm{H}_{2} 0(\mathrm{~B}) \\
0.05 \% \text { formic acid }+\mathrm{MeCN}\end{array}$ & $\begin{array}{l}\mathrm{m} / \mathrm{z} \text { values of } 85 \rightarrow 68 \text { for DCD } \\
\text { and } \mathrm{m} / \mathrm{z} 168.2 \rightarrow 74 \text { for NBPT }\end{array}$ & $25 \& 5$ respectively & [119] \\
\hline $\begin{array}{l}\text { LC-ESI-MS/MS } \\
\text { (Positive mode) }\end{array}$ & $\begin{array}{l}\text { DCD, NBPT, 2-NPT, } \\
\text { 1H-1,2,4-triazole, } \\
\text { and } 3 \mathrm{MP} \text {, and } \\
\text { 3,4-DMPP }\end{array}$ & Water & Dillution & $\begin{array}{l}\text { Hypercarb } \\
\text { column } \\
(150 \times 2.1 \mathrm{~mm} \\
5 \mu \mathrm{m})\end{array}$ & $\begin{array}{l}\text { (A) } 0.01 \% \text { formic acid in } \mathrm{H}_{2} \mathrm{O} \& \\
\text { (B) } \mathrm{MeOH} \text { and } 0.01 \% \text { formic } \\
\text { acid }\end{array}$ & $\begin{array}{c}\mathrm{m} / \mathrm{z} \text { vaules } 85.0 \rightarrow 68.042 .9 \\
168.1 \rightarrow 95.074 .0,217.0 \rightarrow \\
199.9121 .0,73.0 \rightarrow 44.0,83.0 \rightarrow \\
42.056 .1,97.0 \rightarrow 56.142 .0 \\
\text { respectively }\end{array}$ & $\begin{array}{l}20,30,50,100 \text { and } \\
250 \text { respectively }\end{array}$ & [120] \\
\hline $\begin{array}{c}\text { LC/MS/MS } \\
\text { (Positive mode) }\end{array}$ & NBPT & $\begin{array}{l}\text { Milk, Tissues } \\
\text { (Liver, Kidney, } \\
\text { Mussel, Fat) }\end{array}$ & $\begin{array}{l}\text { Homogenization \& } \\
\text { extracted with } \\
\text { acetonitrile }\end{array}$ & $\begin{array}{l}\text { Luna C8 column } \\
(50 \times 2 \mathrm{~mm}, 3 \mu \mathrm{m})\end{array}$ & $\begin{array}{l}\text { (A) } 0.2 \% \text { formic acid and } \\
0.012 \% \mathrm{NH}_{4} \mathrm{OH} \text { in } \mathrm{H}_{2} \mathrm{O} \text { and (B) } \\
\text { MeCN. }\end{array}$ & $\begin{array}{l}168.1 \mathrm{~m} / \mathrm{z} \text { and product ion } 74 \\
\mathrm{~m} / \mathrm{z}\end{array}$ & $\begin{array}{l}50 \text { in milk samples } \\
\text { and } 40 \text { in tissue } \\
\text { samples }\end{array}$ & [68] \\
\hline $\begin{array}{l}\text { HPLC/ESI/QTOF } \\
\text { (Positive mode) }\end{array}$ & NBPT, NBPTo, NBA & Soil & $\begin{array}{l}\text { Extraction with } \\
\text { deionised water and } \\
\text { centrifugation }\end{array}$ & $\begin{array}{c}\text { RRHD } \\
(50 \times 2.1 \mathrm{~mm} \\
1.8 \mu \mathrm{m}) \mathrm{C} 18\end{array}$ & $\begin{array}{l}\text { (A) } 20 \mathrm{mM} \text { ammonium formate } \\
\text { (pH 6.5) \& (B) MeCN }\end{array}$ & $\begin{array}{c}{[\mathrm{M}+\mathrm{H}]+(168.02 \mathrm{~m} / \mathrm{z}),} \\
{[\mathrm{M}+\mathrm{Na}]+(190.063), \text { decay ions: }} \\
{[\mathrm{NBPTo}+\mathrm{Na}]+(174.084),} \\
{[\mathrm{NBPTo}+\mathrm{H}]+(152.090),} \\
151.046, \text { and } 135.071 . \mathrm{NBA} \\
\text { derivativem } / \mathrm{z}=252.064\end{array}$ & 0.3 nmole g- 1 & [56] \\
\hline HPLC & DCD & $\begin{array}{c}\text { Soil extracts, } \\
\text { bacterial } \\
\text { cultures, culture } \\
\text { filtrates } \\
\end{array}$ & $\begin{array}{l}\text { Dilution, } \\
\text { Deprotaination and } \\
\text { centrifugation }\end{array}$ & $\begin{array}{l}\text { Prepacked cation } \\
\text { H+-column } \\
(30 \times 4.6 \mathrm{~mm})\end{array}$ & $\begin{array}{l}\text { Isocratic elution with } 0.025 \mathrm{M} \\
\mathrm{HeSO}_{4}\end{array}$ & N/A & 500 & [121] \\
\hline $\begin{array}{c}\text { LC/MS/MS } \\
\text { (Positive mode) }\end{array}$ & $\mathrm{DCD} \& 15 \mathrm{~N}_{4}-\mathrm{DCD}$ & Infant formula & $\begin{array}{l}\text { Microwave-assisted } \\
\text { extraction with } \\
\text { solid-phase extraction }\end{array}$ & $\begin{array}{l}\text { ZIC-HILIC HPLC } \\
\text { column } \\
(150 \times 2.1 \mathrm{~mm} \text { i.d., } \\
5-\mu \mathrm{m})\end{array}$ & $\begin{array}{l}\text { (A) } 20 \mathrm{mM} \text { ammonium acetate } \\
\text { (B) MeCN }\end{array}$ & $85.0,68.02,43.089 .0,71.02,45.0$ & 3 and 10 & [122] \\
\hline $\begin{array}{c}\text { LC/MS/MS } \\
\text { (Positive mode) }\end{array}$ & $\begin{array}{c}\text { DCD, Urea, } \\
\text { Biuret,Cyromazine, } \\
\text { Triuret, } \\
\text { Amidinourea, } \\
\text { Melamine }\end{array}$ & $\begin{array}{l}\text { Wheat Flower \& } \\
\text { Skim Milk }\end{array}$ & $\begin{array}{l}\text { Extraction with } 0.2 \% \\
\text { formic acid and } \mathrm{MeCN}, \\
\text { Centrifugation, } \\
\text { Filtration }(0.20 \mu \mathrm{m})\end{array}$ & $\begin{array}{l}\text { ZIC-HILIC } \\
(150 \mathrm{~mm} \times 2.1 \mathrm{~mm}, \\
5 \mu \mathrm{m})\end{array}$ & $\begin{array}{c}\text { (A) }(95: 5 \text { ACN:0.1\% formic } \\
\text { acid/10 mM ammonium } \\
\left.\text { formate in } \mathrm{H}_{2} \mathrm{O}\right)(\mathrm{B})(50: 50 \\
\text { ACN:0.1\% formic acid } / 10 \mathrm{mM} \\
\left.\text { ammonium formate in } \mathrm{H}_{2} \mathrm{O}\right)\end{array}$ & $\begin{array}{c}85.0 \rightarrow 68.0 \rightarrow 43.1,61.0 \rightarrow 44.0, \\
104.1 \rightarrow 61.0 \rightarrow 44.0,147.1 \rightarrow \\
130.1 \rightarrow 104.1 \rightarrow 61.1,167.1 \rightarrow \\
85.1 \rightarrow 125 \rightarrow 68.0,103.1 \rightarrow 60.1 \\
\rightarrow 43.1,127.0 \rightarrow 85.0 \rightarrow 68.0\end{array}$ & $\begin{array}{c}(18,60),(4320, \\
28800),(54,240),(18, \\
180),(18,180),(54, \\
240),(162,480)\end{array}$ & [123] \\
\hline
\end{tabular}


The majority of chromatographic methods for analyzing urease and nitrification inhibitors including NBPT have been developed for environmental matrices (Table 10). NBPT and NBPTo are polar residues and can be retained on reverse-phase HPLC systems.

Douglass and Hendrickson [116] reported an early method that allowed the simultaneous analysis of NBPT and NBPTo using a $\mathrm{C}_{18}$ separation and post-column derivatization with fluorescence detection (Figure 3). Following separation, the analytes were sequentially hydrolyzed to n-butylamine with nitric acid at $155^{\circ} \mathrm{C}$ and then converted to fluorescent derivatives using o-phthaladehyde (OPA). The authors found that a 1000-fold improvement in sensitivity could be achieved using fluorescent detection compared with HPLC-UV.

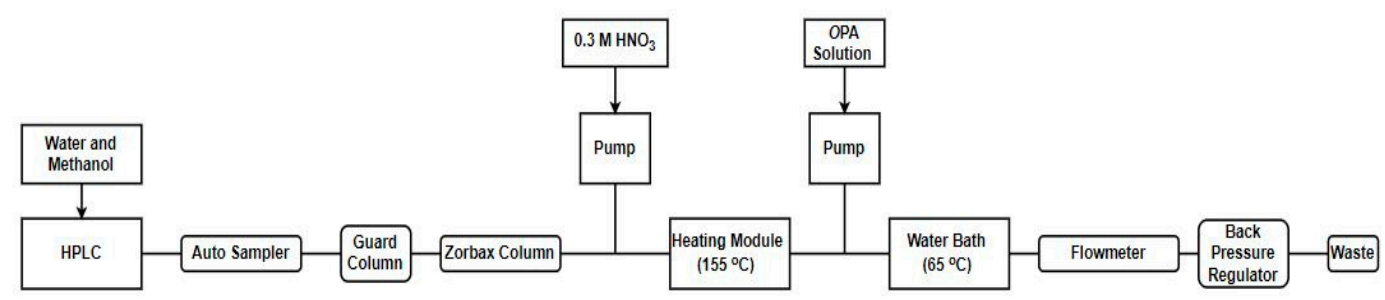

Figure 3. Schematic diagram of HPLC and post-column reaction system as used by Douglass and Hendrickson [116].

Douglass and Hendrickson [116] conducted a 14-day stability study in which solutions of NBPT and NBPTo were stored at $-20,4$, and $25^{\circ} \mathrm{C}$ and found that solutions of NBPT and NBPTo can be stored at room temperature or refrigerated for $14 \mathrm{~d}$. Decomposition was significantly accelerated especially in acidic solutions upon freezing; therefore, methanol must be added to solutions stored below $0{ }^{\circ} \mathrm{C}$ to ensure that they do not freeze.

Engel et al. 2015 [56] used HPLC-MS and quantified NBA in soil extracts using a modified OPA and sodium sulfite derivatization protocol. The authors reported that both NBPT and NBPTo were unstable in acid $\mathrm{pH}$ hydrolyzing to NBA at room temperature and concluded that NBPT and NBPTo breakdown is highly influenced by $\mathrm{pH}$ with chemical hydrolysis being the dominant pathway at $\mathrm{pH}$ (5.1-7.6) and microbial hydrolysis becoming the dominant pathway at $\mathrm{pH}$ (8.2).

LC-MS/MS has been used by a number of groups for the detection of various inhibitors in fertilizers, water, and food samples. A recent method for the detection of NBPT in milk and various edible tissue samples was established by van de ligt et al. 2019 [68] (Table 10). The authors reported that NBPT residues were found to be unstable in milk samples and required storage at $-80{ }^{\circ} \mathrm{C}$ to ensure stability. This agrees with the previous findings by Engel et. al. [56]. One possible explanation for the instability of NBPT in milk, could be due to its $\mathrm{pH}$ which is generally slightly acidic (pH between 6.5 and 6.7). Thus, $\mathrm{pH}$ and temperature control are critical to the analysis of NBPT and NBPTo residues in milk.

Methods for the detection of DCD in various matrices are also summarized in (Table 10). An early HPLC method developed by Schwarzer and Haselwandter was used to detect DCD in soil [120]. This method has been adapted and utilized by Welten et al. [107] to assess excretion routes of DCD in cattle that received repeat oral administration of the compound and how its ultimate excretion in urine influenced its efficacy in soil. Welten et al. 2016 [108] also assessed the oral administration of DCD to lactating dairy cows and its effect and presence as a residue in milk; the study also assessed the efficacy of DCD delivery via a supplementary feed $[107,108]$. Some more recent techniques for the detection of DCD in milk and infant formula include ultra-fast liquid chromatography-tandem quadrupole mass spectrometry (UFLC-MS/MS) [123], hydrophilic interaction liquid chromatography with tandem mass spectrometry (HILIC-MS/MS) [124,125], UV spectroscopy, and UV spectrophotometry [126,127].

There are also various methods currently available for the analysis of multiple inhibitors. One validated method published in 2018 utilized an LC-MS/MS for the detection of both NBPT and DCD in a urea fertilizer matrix (Table 10). Previous literature stated that NBPT and DCD co-elute during separation and therefore, an Obelsc-R column $(4.6 \times 150 \mathrm{~mm}, 5 \mathrm{um}$ particle size $)$ 
was utilized. Due to the presence of both positively charged (quaternary amine like) and negatively charged (carboxyl type) ions in the columns stationary phase, which aided separation through added electrostatic interactions and repulsions of target analytes, both target analytes were linear over a range of 1.0-15 ppm. The respective limits of detection of each of the target analytes were found to be 25 and $5 \mu \mathrm{g} / \mathrm{kg}$, with recoveries of 96.7 to $105 \%$ [118].

Marco Scheurer et al. (2016) investigated the occurrence and fate of nitrification and urease inhibitors in the aquatic environment (Table 10). The method utilized an LC-ESI-MS/MS with an (Applied Biosystems/MDS Sciex API 5500 Q-Trap triple-quadrupole). The method was developed for the detection of various nitrification and urease inhibitors including DCD, NBPT, 2-NPT, 1H-1,2,4-triazole, and $3 \mathrm{MP}$, and 3,4-DMPP. Achieving LOQs of 20, 30, 50, 100, and $250 \mu \mathrm{g} / \mathrm{kg}$, respectively [119].

Other methods for the detection of urease inhibitors include colorimetric detection utilizing gold nanoparticles for the detection of urea, urease, and urease inhibitors [128]. Urease inhibition can also be detected utilizing a fluorometric assay on a multilayer microfluidic chip with immunoaffinity immobilized enzyme reactors [129].

\section{Conclusions}

The potential of urease and nitrification inhibitors to lower greenhouse gas emissions from the mass application of agricultural fertilizers has long been recognized. Such inhibitor technologies have the potential to greatly improve the sustainability of the grass-fed dairy industry. Although previous research suggests that the risk of inhibitors contaminating milk and dairy products is low, further studies are required to ensure that these additives do not pose any substantial threat to food safety and human health. The development of accurate and robust analytical methods for the detection of urease and nitrification inhibitors at residual levels in foods is also required. Modeling studies are required to predict the fate of urease and nitrification inhibitors in the environment and to identify and map their potential to become residual contaminants. Such research can be used to drive the regulation and implementation of MRLs for dairy products. Helping to ensure sustainable agri-industry growth targets while protecting the environment and safeguarding the quality of dairy products is key to viable farming practices in the future. The correct use of urease and nitrification inhibitors is well documented to promote significant reductions in $\mathrm{N}_{2} \mathrm{O}$ and $\mathrm{NH}_{3}$ emissions from agriculture and offers enormous potential for the development of a more sustainable dairy industry. Better knowledge on the implications of their use on the environment, food production, and human health can only help to establish their full potential as a means of achieving globally accepted climate change targets.

Author Contributions: Conceptualization, M.P.B.; Investigation, M.P.B.; Writing-Original Draft Preparation, M.P.B., P.J.F and T.F.O.; Writing-Review and Editing, M.P.B., T.F.O., S.A.H., E.C., M.D., C.G.N., P.J.F., K.R. and J.T.T.; Supervision, T.F.O., S.A.H., and E.C.; Project Administration, P.J.F., K.R. and J.T.T. All authors have read and agreed to the published version of the manuscript.

Funding: The authors would like to thank the Department of Agriculture Food and the Marine DAFM for project funding (17F207), Teagasc and University College Dublin.

Conflicts of Interest: The authors declare no conflict of interest.

\section{References}

1. Hertel, T.W. The global supply and demand for agricultural land in 2050: A perfect storm in the making? Am. J. Agric. Econ. 2011, 93, 259-275. [CrossRef]

2. Irish Department of Communications, Climate and Environoment-National Mitigation Plan July 2017 Ireland. Available online: https://www.dccae.gov.ie/en-ie/climate-action/publications/Documents/ 7/National\%20Mitigation\%20Plan\%202017.pdf (accessed on 9 June 2020).

3. European Commission. 2020 Climate E Energy Package; European Commission: Brussels, Belgium, 2009.

4. EuropeanCommission. 2030 Climate E Energy Framework; European Commission: Brussels, Belgium, 2014.

5. EuroStat. Agri-Environmental Indicator-Greenhouse Gas Emission; European Commission: Brussels, Belgium, 2017. 
6. EPA. Ireland's Greenhouse Gas Emission Projections 2012-2030; Envionmental Protection Agency: Washington, DC, USA, 2013.

7. Roche, L.; Forrestal, P.; Lanigan, G.; Richards, K.; Shaw, L.; Wall, D. Impact of fertiliser nitrogen formulation, and $\mathrm{N}$ stabilisers on nitrous oxide emissions in spring barley. Agric. Ecosyst. Environ. 2016, 233, 229-237. [CrossRef]

8. Minet, E.; Jahangir, M.; Krol, D.; Rochford, N.; Fenton, O.; Rooney, D.; Lanigan, G.; Forrestal, P.; Breslin, C.; Richards, K.; et al. Amendment of cattle slurry with the nitrification inhibitor dicyandiamide during storage: A new effective and practical $\mathrm{N}_{2} \mathrm{O}$ mitigation measure for landspreading. Agric. Ecosyst. Environ. 2016, 215, 68-75. [CrossRef]

9. Cantarella, H.; Otto, R.; Soares, J.R.; Silva, A.G.; de Brito, S. Agronomic efficiency of NBPT as a urease inhibitor: A review. J. Adv. Res. 2018, 13, 19-27. [CrossRef] [PubMed]

10. Danaher, M.; Jordan, K. Identification of existing and emerging chemical residue contamination concerns in milk. Ir. J. Agric. Food Res. 2013, 52, 173-183.

11. Singh, S.N.; Verma, A. The potential of nitrification inhibitors to manage the pollution effect of nitrogen fertilizers in agricultural and other soils: A review. Environ. Rev. 2007, 9, 266-279. [CrossRef]

12. Change, C. Synthesis Report of the IPCC Fifth Assessment Report; IPCC: Geneva, Switzerlad, 2014.

13. Forster, P.; Ramaswamy, V.; Artaxo, P.; Berntsen, T.; Betts, R.; Fahey, D.W.; Haywood, J.; Lean, J.; Lowe, D.C.; Myhre, G.; et al. Changes in atmospheric constituents and in radiative forcing. Chapter 2. In Climate Change 2007; The Physical Science Basis; IPCC: Geneva, Switzerlad, 2007.

14. Hyde, B.; Forrestal, P.J.; Jahangir, M.M.; Ryan, M.; Fanning, A.; Carton, O.T.; Lanigan, G.; Richards, K.G. The interactive effects of fertiliser nitrogen with dung and urine on nitrous oxide emissions in grassland. Ir. J. Agric. Food Res. 2016, 55, 1-9. [CrossRef]

15. Burger, M.; Venterea, R.T. Understanding Greenhouse Gas Emissions from Agricultural Management; Guo, L., Gunasekara, A.S., McConnell, L.L., Eds.; American Chemical Society: Washington, DC, USA, 2011; Volume 1072, pp. 179-202.

16. Bøckman, O.C.; Olfs, H.W. Fertilizers, agronomy and $\mathrm{N}_{2} \mathrm{O}$. Nutr. Cycl. Agroecosyst. 1998, 52, $165-170$. [CrossRef]

17. Signor, D.; Cerri, C.E.P. Nitrous oxide emissions in agricultural soils: A review. Pesqui. Agropecuária Trop. 2013, 43, 322-338. [CrossRef]

18. Minick, K.; Pandey, C.; Fox, T.; Subedi, S. Dissimilatory nitrate reduction to ammonium and $\mathrm{N}_{2} \mathrm{O}$ flux: Effect of soil redox potential and N fertilization in loblolly pine forests. Biol. Fertil. Soils 2016, 52, 601-614. [CrossRef]

19. Florio, A.; Bréfort, C.; Gervaix, J.; Bérard, A.; Le Roux, X. The responses of $\mathrm{NO}_{2}$-and $\mathrm{N}_{2} \mathrm{O}$-reducing bacteria to maize inoculation by the PGPR Azospirillum lipoferum CRT1 depend on carbon availability and determine soil gross and net $\mathrm{N}_{2} \mathrm{O}$ production. Soil Biol. Biochem. 2019, 136, 107524. [CrossRef]

20. Ferrara, R.M.; Loubet, B.; Decuq, C.; Palumbo, A.D.; Di Tommasi, P.; Magliulo, V.; Masson, S.; Personne, E.; Cellier, P.; Rana, G.; et al. Ammonia volatilisation following urea fertilisation in an irrigated sorghum crop in Italy. Agric. For. Meteorol 2014, 195-196, 179-191. [CrossRef]

21. Hyde, B.P.; Carton, O.T.; O'Toole, P.; Misselbrook, T.H. A new inventory of ammonia emissions from Irish agriculture. Atmos. Environ. 2003, 37, 55-62. [CrossRef]

22. Zaman, M.; Nguyen, M.; Blennerhassett, J.; Quin, B. Reducing $\mathrm{NH}_{3}, \mathrm{~N}_{2} \mathrm{O}$ and $\mathrm{NO}_{3}-\mathrm{N}$ losses from a pasture soil with urease or nitrification inhibitors and elemental S-amended nitrogenous fertilizers. Biol. Fertil. Soils 2008, 44, 693-705. [CrossRef]

23. Harty, M.A.; Forrestal, P.J.; Watson, C.J.; McGeough, K.L.; Carolan, R.; Elliot, C.; Krol, D.; Laughlin, R.J.; Richards, K.G.; Lanigan, G.J.; et al. Reducing nitrous oxide emissions by changing June d N fertiliser use from calcium ammonium nitrate (CAN) to urea based formulations. Sci. Total Environ. 2016, 563-564, 576-586. [CrossRef]

24. Gilsanz, C.; Báez, D.; Misselbrook, T.H.; Dhanoa, M.S.; Cárdenas, L.M. Development of emission factors and efficiency of two nitrification inhibitors, DCD and DMPP. Agric. Ecosyst. Environ. 2016, 216, 1-8. [CrossRef]

25. Shibata, H.; Branquinho, C.; McDowell, W.H.; Mitchell, M.J.; Monteith, D.T.; Tang, J.; Arvola, L.; Cruz, C.; Cusack, D.F.; Halada, L.; et al. Consequence of altered nitrogen cycles in the coupled human and ecological system under changing climate: The need for long-term and site-based research. Ambio 2015, 44, 178-193. [CrossRef] 
26. Kafarski, P.; Talma, M. Recent advances in design of new urease inhibitors: A review. J. Adv. Res. 2018, 13, 101-112. [CrossRef]

27. Overrein, L.N.; Moe, P.G. Factors affecting urea hydrolysis and ammonia volatilization in soil1. Soil Sci. Soc. Am. J. 1967, 31, 57-61. [CrossRef]

28. COMMISSION REGULATION (EC) No 1107/2008 of Amending Regulation (EC) No 2003/2003 of the European Parliament and of the Council Relating to Fertilisers; European Parliament: Brussel, Belgium, 7 November 2008.

29. The European Food Safty Authority. Opinion of the Scientific Panel on Food Additives, Flavourings, Processing Aids and Materials in Contact with Food on a request from the Commission related toCreatine monohydrate for use in foods for particular nutritional uses Question number EFSA-Q-2003-12. EFSA J. 2004, 36, 1-6. [CrossRef]

30. REGULATION (EC) No 2003/2003 of the European Parliament and of the Council of 13 October 2003 Relating to Fertilisers; Europian Parliament: Brussel, Belgium, 2003.

31. European Commission. COMMISSION REGULATION (EU) No 1257/2014 Amending Regulation (EC) No 2003/2003; Eurpoean Parliament: Brussel, Belgium, 2014.

32. The European Chemicals Agency ECHA. Nitrapyrin. Available online: https://echa.europa.eu/substanceinformation/-/substanceinfo/100.016.076 (accessed on 9 June 2020).

33. European Commission. COMMISSION REGULATION (EU) 2019/1102; European Parliament: Brussel, Belgium, 2019.

34. Manunza, B.; Deiana, S.; Pintore, M.; Gessa, C. The binding mechanism of urea, hydroxamic acid and $\mathrm{N}-(\mathrm{N}$-butyl)-phosphoric triamide to the urease active site. A comparative molecular dynamics study. Soil Biol. Biochem. 1999, 31, 789-796. [CrossRef]

35. Kumari, D.; Qian, X.Y.; Pan, X.; Achal, V.; Li, Q.; Gadd, G.M. Microbially-induced carbonate precipitation for immobilization of toxic metals. In Advances in Applied Microbiology; Elsevier: Amsterdam, The Netherlands, 2016; Volume 94, pp. 79-108.

36. Hadjipavlou-Litina, D.; Gupta, S.P. Design and development of inhibitors of herpes viral proteases and their SAR and QSAR. In Viral Proteases and Their Inhibitors; Elsevier: Amsterdam, The Netherlands, 2017; pp. 441-467.

37. Shah, M.R.; Soomro, Z.H. Urease inhibition. In Enzyme Inhibition and Bioapplications; InTech: London, UK, 2012.

38. Upadhyay, L.S.B. Urease Inhibitors: A Review; NISCAIR-CSIR: New Delhi, India, 2012.

39. Engelking, L.R. Textbook of Veterinary Physiological Chemistry, Updated 2/e; Academic Press: Cambridge, MA, USA, 2010.

40. Krajewska, B.; Ureases, I. Functional, catalytic and kinetic properties: A review. J. Mol. Catal. B. Enzym. 2009, 59, 9-21. [CrossRef]

41. Mazzei, L.; Cianci, M.; Benini, S.; Ciurli, S. The impact of $\mathrm{pH}$ on catalytically critical protein conformational changes: The case of the urease, a nickel enzyme. Chem. Eur. J. 2019, 25, 12145-12158. [CrossRef] [PubMed]

42. Mazzei, L.; Cianci, M.; Contaldo, U.; Musiani, F.; Ciurli, S. Urease inhibition in the presence of N-(n-Butyl) thiophosphoric triamide, a suicide substrate: Structure and kinetics. Biochemistry 2017, 56, 5391-5404. [PubMed]

43. Karamanos, R.; Holzapfel, C.; Nybo, B.; Puurveen, D.; Shirtliffe, S. The impact of DCD and NBPT concentration on nitrification and volatilization. In Proceedings of the Soils and Crops Workshop, Saskatoon, SK, Canada, 9-10 March 2019.

44. Ning, J.; Ai, S.; Cui, L. Dicyandiamide has more inhibitory activities on nitrification than thiosulfate. PLoS ONE 2018, 13, e0200598. [CrossRef]

45. Ruser, R.; Schulz, R. The effect of nitrification inhibitors on the nitrous oxide $\left(\mathrm{N}_{2} \mathrm{O}\right)$ release from agricultural soils-A review. J. Plant Nutr. Soil Sci. 2015, 178, 171-188. [CrossRef]

46. Torralbo, F.; Menéndez, S.; Barrena, I.; Estavillo, J.M.; Marino, D.; González-Murua, C. Dimethyl pyrazol-based nitrification inhibitors effect on nitrifying and denitrifying bacteria to mitigate $\mathrm{N}_{2} \mathrm{O}$ emission. Sci. Rep . 2017, 7, 1-11. [CrossRef]

47. Forrestal, P.J.; Harty, M.; Carolan, R.; Lanigan, G.J.; Watson, C.J.; Laughlin, R.J.; McNeill, G.; Chambers, B.J.; Richards, K.G. Ammonia emissions from urea, stabilized urea and calcium ammonium nitrate: Insights into loss abatement in temperate grassland. Soil Use Manag. 2016, 32, 92-100. [CrossRef]

48. Watson, C.J.; Miller, H. Short-term effects of urea amended with the urease inhibitor N-(n-butyl) thiophosphoric triamide on perennial ryegrass. Plant Soil 1996, 184, 33-45. [CrossRef] 
49. Forrestal, P.J.; Harty, M.A.; Carolan, R.; Watson, C.J.; Lanigan, G.J.; Wall, D.P.; Hennessy, D.; Richards, K.G. Can the agronomic performance of urea equal calcium ammonium nitrate across nitrogen rates in temperate grassland? Soil Use Manag. 2017, 33, 243-251. [CrossRef]

50. Domínguez, M.J.; Sanmartín, C.; Font, M.; Palop, J.A.; San Francisco, S.; Urrutia, O.; Houdusse, F.; García-Mina, J.M. Design, synthesis, and biological evaluation of phosphoramide derivatives as urease inhibitors. J. Agric. Food Chem. 2008, 56, 3721-3731. [CrossRef] [PubMed]

51. Rochette, P.; MacDonald, J.D.; Angers, D.A.; Chantigny, M.H.; Gasser, M.O.; Bertrand, N. Banding of urea increased ammonia volatilization in a dry acidic soil. J. Environ. Qual. 2009, 38, 1383-1390. [CrossRef] [PubMed]

52. Engel, R.; Williams, E.; Wallander, R.; Hilmer, J. Apparent persistence of N-(n-butyl) thiophosphoric triamide is greater in alkaline soils. Soil Sci. Soc. Am. J. 2013, 77, 1424-1429. [CrossRef]

53. The European Chemicals Agency ECHA. [diamino(sulfanylidene)-lambda5-phosphanyl](propyl)amine. Available online: https://echa.europa.eu/substance-information/-/substanceinfo/100.127.866 (accessed on 9 June 2020).

54. Pro, D.; Huguet, S.; Arkoun, M.; Nugier-Chauvin, C.; Garcia-Mina, J.M.; Ourry, A.; Wolbert, D.; Yvin, J.C.; Ferrières, V. From algal polysaccharides to cyclodextrins to stabilize a urease inhibitor. Carbohydr. Polym. 2014, 112, 145-151. [CrossRef] [PubMed]

55. The Australian Governoment Department of Health and Aging; National Industrial Chemicals Notification and Assessment Scheme NICNAS. Existing Chemical Secondary Notification Assessment NA/467S N-(n-butyl) Thiophosphoric Triamide (NBPT) Aging; The Australian Governoment Department of Health and Aging: Sydney, Australia, 2011.

56. Engel, R.E.; Towey, B.D.; Gravens, E. Degradation of the urease inhibitor NBPT as affected by soil pH. Soil Sci. Soc. Am. J. 2015, 79, 1674-1683. [CrossRef]

57. The European Chemicals Agency. NPPT; ECHA: Helsinki, Finland, 2019.

58. The European Chemicals Agency ECHA. N-(2-nitrophenyl)phosphoric Triamide. Available online: https: //echa.europa.eu/substance-information/-/substanceinfo/100.105.163 (accessed on 9 June 2020).

59. The European Chemicals Agency ECHA. Cyanoguanidine. Available online: https://echa-term.echa.europa. eu/da/web/guest/substance-information/-/substanceinfo/100.006.649 (accessed on 9 June 2020).

60. The European Chemicals Agency ECHA. 3,4-Dimethyl-1H-pyrazol-1-ium Dihydrogen Phosphate. Available online: https:/echa.europa.eu/substance-information/-/substanceinfo/100.102.315 (accessed on 9 June 2020).

61. Marsden, K.A.; Marín-Martínez, A.J.; Vallejo, A.; Hill, P.W.; Jones, D.L.; Chadwick, D.R. The mobility of nitrification inhibitors under simulated ruminant urine deposition and rainfall: A comparison between DCD and DMPP. Biol. Fertility Soils 2016, 52, 491-503. [CrossRef]

62. Tao, L.; Yuanliang, S.; Xuewen, L.; Guolin, L. Degradation and its affecting factors of NBPT in soil. Chin. J. Ecol. 2006, 25, 1082-1086.

63. ECHA, E.C.A. Pre-registered Reach Substances. Available online: https://echa.europa.eu/information-onchemicals/pre-registered-substances/-/dislist/substance/100.112.861 (accessed on 5 June 2019).

64. Leo, A.; Hansch, C.; Elkins, D. Partition coefficients and their uses. Chem. Rev. 1971, 71, 525-616. [CrossRef]

65. The Australian Governoment Department of Health and Aging; National Industrial Chemicals Notification and Assessment Scheme NICAS. N-(n-butyl) Thiophosphoric Triamide (NBPT) Aging; The Australian Governoment Department of Health and Aging: Sydney, Australia, 1997.

66. Silva, A.G.; Sequeira, C.H.; Sermarini, R.A.; Otto, R. Urease inhibitor NBPT on ammonia volatilization and crop productivity: A meta-analysis. Agron. J. 2017, 109, 1-13. [CrossRef]

67. Ramaty, E.; Maor, E.; Peltz-Sinvani, N.; Brom, A.; Grinfeld, A.; Kivity, S.; Segev, S.; Sidi, Y.; Kessler, T.; Sela, B.; et al. Low ALT blood levels predict long-term all-cause mortality among adults. A historical prospective cohort study. Eur. J. Intern. Med. 2014, 25, 919-921.

68. Van de Ligt, J.; Borghoff, S.J.; Yoon, M.; Ferguson, L.J.; DeMaio, W.; McClanahan, R.H. Nondetectable or minimal detectable residue levels of $\mathrm{N}$-(n-butyl) thiophosphoric triamide in bovine tissues and milk from a 28-d NBPT dosing study. Transl. Anim. Sci. 2019, 3. [CrossRef]

69. Li, Q.; Yang, A.; Wang, Z.; Roelcke, M.; Chen, X.; Zhang, F.; Pasda, G.; Zerulla, W.; Wissemeier, A.H.; Liu, X.; et al. Effect of a new urease inhibitor on ammonia volatilization and nitrogen utilization in wheat in north and northwest China. Field Crops Res. 2015, 175, 96-105. [CrossRef] 
70. Li, S.; Li, J.; Lu, J.; Wang, Z. Effect of mixed urease inhibitors on N losses from surface-applied urea. Intern. J. Agric. Sci. Technol. 2015, 3, 23-27. [CrossRef]

71. Li, Q.; Cui, X.; Liu, X.; Roelcke, M.; Pasda, G.; Zerulla, W.; Wissemeier, A.H.; Chen, X.; Goulding, K.; Zhang, F.; et al. A new urease-inhibiting formulation decreases ammonia volatilization and improves maize nitrogen utilization in North China Plain. Sci. Rep. 2017, 7, 43853. [CrossRef] [PubMed]

72. Ni, K.; Kage, H.; Pacholski, A. Effects of novel nitrification and urease inhibitors (DCD/TZ and 2-NPT) on $\mathrm{N}_{2} \mathrm{O}$ emissions from surface applied urea: An incubation study. Atmos. Environ. 2018, 175, 75-82. [CrossRef]

73. Ni, K.; Pacholski, A.; Kage, H. Ammonia volatilization after application of urea to winter wheat over 3 years affected by novel urease and nitrification inhibitors. Agric. Ecosyst. Environ. 2014, 197, 184-194. [CrossRef]

74. Schraml, M.; Gutser, R.; Schmidhalter, U. Abatement of $\mathrm{NH}_{3}$ emissions following application of urea to grassland by means of the new urease inhibitor 2-NPT. In Proceedings of the 18th Symposium of the International Scientific Centre of Fertilizers, Rome, Italy, 8-12 November 2010.

75. Kirschke, T.; Spott, O.; Vetterlein, D. Impact of urease and nitrification inhibitor on $\mathrm{NH}_{2}{ }^{+}$and $\mathrm{NO}_{3}{ }^{-}$dynamic in soil after urea spring application under field conditions evaluated by soil extraction and soil solution sampling. J. Plant Nutr. Soil Sci. 2019, 182, 441-450. [CrossRef]

76. Lan, T.; Han, Y.; Roelcke, M.; Nieder, R.; Cai, Z. Effects of the nitrification inhibitor dicyandiamide (DCD) on gross $\mathrm{N}$ transformation rates and mitigating $\mathrm{N}_{2} \mathrm{O}$ emission in paddy soils. Soil Biol. Biochem. 2013, 67, 174-182. [CrossRef]

77. Skiba, U.; Smith, K.A.; Fowler, D. Nitrification and denitrification as sources of nitric oxide and nitrous oxide in a sandy loam soil. Soil Biol. Biochem. 1993, 25, 1527-1536. [CrossRef]

78. McTaggart, I.; Clayton, H.; Parker, J.; Swan, L.; Smith, K.A. Nitrous oxide emissions from grassland and spring barley, following $\mathrm{N}$ fertiliser application with and without nitrification inhibitors. Biol. Fertil. Soils 1997, 25, 261-268. [CrossRef]

79. McGeough, K.L.; Watson, C.J.; Müller, C.; Laughlin, R.J.; Chadwick, D.R. Evidence that the efficacy of the nitrification inhibitor dicyandiamide (DCD) is affected by soil properties in UK soils. Soil Biol. Biochem. 2016, 94, 222-232. [CrossRef]

80. Zerulla, W.; Barth, T.; Dressel, J.; Erhardt, K.; Horchler von Locquenghien, K.; Pasda, G.; Rädle, M.; Wissemeier, A. 3,4-Dimethylpyrazole phosphate (DMPP)-A new nitrification inhibitor for agriculture and horticulture. Biol. Fertil. Soils 2001, 34, 79-84. [CrossRef]

81. Rodrigues, J.M.; Lasa, B.; Aparicio-Tejo, P.M.; González-Murua, C.; Marino, D. 3,4-Dimethylpyrazole phosphate and 2-(N-3,4-dimethyl-1H-pyrazol-1-yl) succinic acid isomeric mixture nitrification inhibitors: Quantification in plant tissues and toxicity assays. Sci. Total Environ. 2018, 624, 1180-1186. [CrossRef] [PubMed]

82. Cahalan, E.; Minet, E.; Ernfors, M.; Müller, C.; Devaney, D.; Forrestal, P.J.; Richards, K.G. The effect of precipitation and application rate on dicyandiamide persistence and efficiency in two Irish grassland soils. Soil Use Manag. 2015, 31, 367-374. [CrossRef]

83. Shepherd, M.; Wyatt, J.; Welten, B. Effect of soil type and rainfall on dicyandiamide concentrations in drainage from lysimeters. Soil Res. 2012, 50, 67-75. [CrossRef]

84. Zacherl, B.; Amberger, A. Effect of the nitrification inhibitors dicyandiamide, nitrapyrin and thiourea onNitrosomonas europaea. Fertil. Res. 1990, 22, 37-44. [CrossRef]

85. Klotz, M.G.; Stein, L.Y. Research on Nitrification and Related Processes; Academic Press: Cambridge, MA, USA, 2011; Volume 496.

86. Cameron, K.C.; Di, H.J.; Moir, J.L. Nitrogen losses from the soil/plant system: A review. Ann. Appl. Biol. 2013, 162, 145-173. [CrossRef]

87. Di, H.J.; Cameron, K.C. The use of a nitrification inhibitor, dicyandiamide (DCD), to decrease nitrate leaching and nitrous oxide emissions in a simulated grazed and irrigated grassland. Soil Use Manag. 2002, 18, 395-403. [CrossRef]

88. Subbarao, G.; Ito, O.; Sahrawat, K.; Berry, W.; Nakahara, K.; Ishikawa, T.; Watanabe, T.; Suenaga, K.; Rondon, M.; Rao, I.M.; et al. Scope and strategies for regulation of nitrification in agricultural systems-Challenges and opportunities. Crit. Rev. Plant Sci. 2006, 25, 303-335. [CrossRef]

89. Kuo, J. Air Pollution Control: Fundamentals and Applications; CRC Press: Boca Raton, FL, USA, 2018.

90. Hauser, M.; Haselwandter, K. Degradation of dicyandiamide by soil bacteria. Soil Biol. Biochem. 1990, 22, 113-114. [CrossRef] 
91. Wilcock, R.; Elliott, S.; Hudson, N.; Parkyn, S.; Quinn, J. Climate change mitigation for agriculture: Water quality benefits and costs. Water Sci. Technol. 2008, 58, 2093-2099. [CrossRef] [PubMed]

92. Espín, S.; García-Fernández, A. Nitrapyrin. In Encyclopedia of Toxicology, 3rd ed.; Elsevier: Amsterdam, The Netherlands, 2014; pp. 519-522.

93. Keiblinger, K.M.; Zehetner, F.; Mentler, A.; Zechmeister-Boltenstern, S. Biochar application increases sorption of nitrification inhibitor 3,4-dimethylpyrazole phosphate in soil. Environ. Sci. Pollut. Res. 2018, 25, 11173-11177. [CrossRef]

94. Huérfano, X.; Fuertes-Mendizábal, T.; Fernández-Diez, K.; Estavillo, J.M.; González-Murua, C.; Menéndez, S. The new nitrification inhibitor 3, 4-dimethylpyrazole succinic (DMPSA) as an alternative to DMPP for reducing $\mathrm{N}_{2} \mathrm{O}$ emissions from wheat crops under humid Mediterranean conditions. Eur. J. Agron. 2016, 80, 78-87. [CrossRef]

95. Pacholski, A.; Berger, N.; Bustamante, I.; Ruser, R.; Guardia, G.; Mannheim, T. Effects of the novel nitrification inhibitor DMPSA on yield, mineral $\mathrm{N}$ dynamics and $\mathrm{N}_{2} \mathrm{O}$ emissions. In Proceedings of the 2016 International Nitrogen Initiative Conference, Solutions to Improve Nitrogen Use Efficiency for the World, Melbourne, Australia, 4-8 December 2016.

96. The European Chemicals Agency ECHA. Reaction Mass of 2-(3,4-Dimethyl-1H-pyrazol-1-yl)succinic Acid and 2-(4,5-Dimethyl-1H-pyrazol-1-yl)succinic Acid. Available online: https://echa.europa.eu/da/registrationdossier/-/registered-dossier/11890/2/3 (accessed on 9 June 2020).

97. Soliman, M.S.; Monem, M.A.A. Effect of method of N-application and modified urea on N-15 recovery by rice. Fertil. Res. 1995, 43, 143-148. [CrossRef]

98. Xu, X.; Zhou, L.; Van Cleemput, O.; Wang, Z. Fate of urea-15N in a soil-wheat system as influenced by urease inhibitor hydroquinone and nitrification inhibitor dicyandiamide. Plant Soil 2000, 220, 261-270. [CrossRef]

99. Gioacchini, P.; Nastri, A.; Marzadori, C.; Giovannini, C.; Antisari, L.V.; Gessa, C. Influence of urease and nitrification inhibitors on $\mathrm{N}$ losses from soils fertilized with urea. Biol. Fertil. Soils 2002, 36, 129-135. [CrossRef]

100. Zanin, L.; Tomasi, N.; Zamboni, A.; Varanini, Z.; Pinton, R. The urease inhibitor NBPT negatively affects DUR3-mediated uptake and assimilation of urea in maize roots. Front. Plant Sci. 2015, 6, 1007. [CrossRef]

101. Cruchaga, S.; Artola, E.; Lasa, B.; Ariz, I.; Ignacio, I.; Moran, J.; Aparicio-Tejo, P. Short term physiological implications of NBPT application on the N metabolism of Pisum sativum and Spinacea oleracea. J. Plant Physiol. 2010, 168, 329-336. [CrossRef]

102. Krogmeier, M.J.; McCarty, G.W.; Bremner, J.M. Potential phytotoxicity associated with the use of soil urease inhibitors. Proc. Natl. Acad. Sci. USA 1989, 86, 1110-1112. [CrossRef]

103. Ariz, I.; Cruchaga, S.; Lasa, B.; Moran, J.F.; Jauregui, I.; Aparicio-Tejo, P.M. The physiological implications of urease inhibitors on $\mathrm{N}$ metabolism during germination of Pisum sativum and Spinacea oleracea seeds. J. Plant Physiol. 2012, 169, 673-681. [CrossRef]

104. Zacharia, J.T. Identity, physical and chemical properties of pesticides. In Pesticides in the Modern World-Trends in Pesticides Analysis; BoD-Books on Demand: Norderstedt, Germany, 2011; pp. 1-18.

105. Constable, P.D.; Hinchcliff, K.W.; Done, S.H.; Grünberg, W. Veterinary Medicine-e-Book: A Textbook of the Diseases of Cattle, Horses, Hheep, Pigs and Goats; Elsevier Health Sciences: Amsterdam, The Netherlands, 2016.

106. O'Connor, P.J.; Hennessy, D.; Lynch, M.B.; Slattery, H.; Lewis, E. The effect of dicyandiamide on rumen and blood metabolites, diet digestibility and urinary excretion. Livest. Sci. 2013, 155, 30-37. [CrossRef]

107. Welten, B.G.; Ledgard, S.F.; Schipper, L.A.; Waller, J.E.; Kear, M.J.; Dexter, M.M. Effects of prolonged oral administration of dicyandiamide to dairy heifers on excretion in urine and efficacy in soil. Agric. Ecosyst. Environ. 2013, 173, 28-36. [CrossRef]

108. Welten, B.; Ledgard, S.; Balvert, S.; Kear, M.; Dexter, M. Effects of oral administration of dicyandiamide to lactating dairy cows on residues in milk and the efficacy of delivery via a supplementary feed source. Agric. Ecosyst. Environ. 2016, 217, 111-118. [CrossRef]

109. Minet, E.; Ledgard, S.; Lanigan, G.; Murphy, J.; Grant, J.; Hennessy, D.; Lewis, E.; Forrestal, P.; Richards, K. Mixing dicyandiamide (DCD) with supplementary feeds for cattle: An effective method to deliver a nitrification inhibitor in urine patches. Agric. Ecosyst. Environ. 2016, 231, 114-121. [CrossRef]

110. Luo, J.; Ledgard, S.; Wise, B.; Welten, B.; Lindsey, S.; Judge, A.; Sprosen, M. Effect of dicyandiamide (DCD) delivery method, application rate, and season on pasture urine patch nitrous oxide emissions. Biol. Fertil. Soils 2015, 51, 453-464. [CrossRef] 
111. Kelsey, J.J. Drug Principles in Lactation. Available online: https://www.accp.com/docs/bookstore/psap/ p2016b3_sample.pdf (accessed on 20 June 2020).

112. Peck, T.; Hill, S.; Williams, M. Drug passage across the cell membrane. In Pharmacology for Anaesthesia and Intensive Care, 2nd ed.; Greenwich Medical Media: London, UK, 2003.

113. Fink-Gremmels, J. Mycotoxins in cattle feeds and carry-over to dairy milk: A review. Food Addit. Contam. 2008, 25, 172-180. [CrossRef]

114. Bhal, S.K. LogP-Making Sense of the Value; Advanced Chemistry Development: Toronto, ON, Canada, 2007; pp. 1-4.

115. Rainard, P. Consequences of interference of milk with chemoattractants for enzyme-linked immunosorbent assay quantifications. Clin. Vaccine Immunol. CVI 2010, 17, 848-852. [CrossRef]

116. Douglass, E.A.; Hendrickson, L.L. HPLC Method for the Analysis of the Urease Inhibitor N-(n-butyl) thiophosphoric Triamide and Its Metabolites. J. Agric. Food Chem. 1991, 39, 2318-2321. [CrossRef]

117. Fertilizers, E. Determination of Urease Inhibitor N-(nbutyl) Thiophosphoric Triamide (NBPT) Using High-Performance Liquid Chromatography (HPLC); European Commission: Brussel, Belgium, 2007.

118. Yogesha, S.; Arun, K.; Shetty, S.G.; Ravi, H.; Ramesh, N. Simultaneous quantification of N-butylthiophosphoric triamide and dicyandiamide in urea formulation by liquid chromatography with tandem mass spectrometry. J. Sep. Sci. 2018, 42, 484-490. [CrossRef]

119. Scheurer, M.; Brauch, H.J.; Schmidt, C.K.; Sacher, F. Occurrence and fate of nitrification and urease inhibitors in the aquatic environment. Environ. Sci. Proces. Impacts 2016, 18, 999-1010. [CrossRef]

120. Schwarzer, C.; Haselwandter, K. Rapid quantification of the nitrification inhibitor dicyandiamide in soil samples, nutrient media and bacterial cell-free extracts. J. Chromatogr. A 1996, 732, 390-393. [CrossRef]

121. Shen, Y.; Han, C.; Zhou, X.; Chen, X.; Huang, F.; Zhu, Z. Microwave-assisted extraction and determination of dicyandiamide residue in infant formula samples by liquid chromatography-tandem mass spectrometry. J. Dairy Sci. 2013, 96, 6877-6882. [CrossRef] [PubMed]

122. MacMahon, S.; Begley, T.H.; Diachenko, G.W.; Stromgren, S.A. A liquid chromatography-tandem mass spectrometry method for the detection of economically motivated adulteration in protein-containing foods. J. Chromatogr. A 2012, 1220, 101-107. [CrossRef] [PubMed]

123. Chen, X.H.; Zhou, L.X.; Zhao, Y.G.; Pan, S.D.; Jin, M.C. Application of nanoring amino-functionalized magnetic polymer dispersive micro-solid-phase extraction and ultra fast liquid chromatography-tandem mass spectrometry in dicyandiamide residue analysis of powdered milk. Talanta 2014, 119, 187-192. [CrossRef] [PubMed]

124. Inoue, K.; Sakamoto, T.; Min, J.Z.; Todoroki, K.; Toyo'oka, T. Determination of dicyandiamide in infant formula by stable isotope dilution hydrophilic interaction liquid chromatography with tandem mass spectrometry. Food Chem. 2014, 156, 390-393. [CrossRef]

125. Draher, J.; Pound, V.; Reddy, T.M. Validation of a rapid method of analysis using ultrahigh-performance liquid chromatography-tandem mass spectrometry for nitrogen-rich adulterants in nutritional food ingredients. J. Chromatogr. A 2014, 1373, 106-113. [CrossRef]

126. Zou, H.; Xu, K.; Feng, Y.; Liang, B. Application of first order derivative UV spectrophotometry coupled with $\mathrm{H}$-point standard addition to the simultaneous determination of melamine and dicyandiamide in milk. Food Anal. Methods 2015, 8, 740-748. [CrossRef]

127. Zou, H.; Zhang, W.; Feng, Y.; Liang, B. Simultaneous determination of melamine and dicyandiamide in milk by UV spectroscopy coupled with chemometrics. Anal. Methods 2014, 6, 5865-5871. [CrossRef]

128. Deng, H.H.; Hong, G.L.; Lin, F.L.; Liu, A.L.; Xia, X.H.; Chen, W. Colorimetric detection of urea, urease, and urease inhibitor based on the peroxidase-like activity of gold nanoparticles. Anal. Chim. Acta 2016, 915, 74-80. [CrossRef]

129. Zhang, Y.; Han, X.; He, N.; Long, M.; Huang, J.; Zhang, G.; Wang, Q.; Han, X. Increase in ammonia volatilization from soil in response to $\mathrm{N}$ deposition in Inner Mongolia grasslands. Atmos. Environ. 2014, 84, 156-162. [CrossRef]

(C) 2020 by the authors. Licensee MDPI, Basel, Switzerland. This article is an open access article distributed under the terms and conditions of the Creative Commons Attribution (CC BY) license (http://creativecommons.org/licenses/by/4.0/). 